International Journal of Earth Sciences

June 2009, Volume 98, Number 4, Pages 751-768

http://dx.doi.org/10.1007/s00531-008-0376-2

(c) 2009 Springer. Part of Springer Science+Business

Media

The original publication is available at http://www.springerlink.com
Archimer, archive institutionnelle de l'Ifremer http://www.ifremer.fr/docelec/

\title{
Overpressure within upper continental slope sediments from CPTU data, Gulf of Lion, NW Mediterranean Sea
}

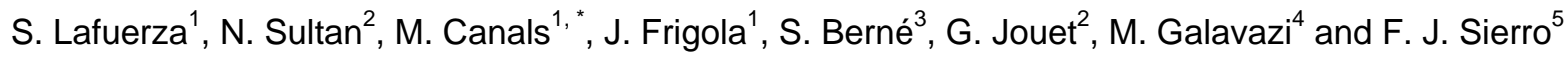 \\ ${ }^{1}$ GRC Geociències Marines, Departament d'Estratigrafia, Paleontologia i Geociències Marines, Universitat de \\ Barcelona, Martí i Franquès s/n, 08028 Barcelona, Spain \\ ${ }^{2}$ Institut Français de Recherche pour l'Exploitation de la Mer (IFREMER), Géosciences Marines, BP 70, 29280 \\ Plouzané, France \\ ${ }^{3}$ Université de Perpignan, 66860 Perpignan, Cedex, France \\ ${ }^{4}$ Fugro Engineers B.V, Veurse Achterweg 10, 2264 SG Leidschendam, The Netherlands \\ ${ }^{5}$ Departamento de Geología, Universidad de Salamanca, Plaza de la Merced s/n, 37008 Salamanca, Spain
}

*: Corresponding author : M. Canals, Tel. +34-934021360, Fax +34-934021340, email address : miquelcanals@ub.edu

\begin{abstract}
:
Data from in situ piezocone tests (CPTU) and laboratory analyses are utilized for the interpretation of the stress history of Quaternary sedimentary sequences in the upper continental slope of the Gulf of Lion, northwestern Mediterranean Sea. A CPTU based preconsolidation pressure profile referenced to the current effective stress indicates that the deposit is underconsolidated from 12 meters below the seafloor (mbsf) down to at least 150 mbsf. Excess pore pressure below $12 \mathrm{mbsf}$ is further supported by results from oedometer and dissipation tests. Subseafloor pockmarks and indications of free gas in seismic reflection profiles reveal four main overpressure sources (SI-SIV) with overpressure ratios $>0.3$ at subseafloor depths coinciding with levels where the dominantly silty-clayey sediment contains increased proportions of sand. We relate the excess pore pressure related to free gas due to gas exsolution processes and sea level variations driven by Pleistocene sea level changes.
\end{abstract}

Keywords: Stress history - Preconsolidation pressure - Overpressure - Continental slope - Gulf of Lion 


\section{Introduction}

Fine-grained sediments such as those occurring in continental slope sequences are particularly prone to develop overpressure (pore fluid pressure in excess of hydrostatic pressure) as they usually exhibit low permeabilities (Bolton et al. 1998). Overpressure drives fluids along permeability pathways and the resulting fluid flow can lower the effective stress of the sediment thus favouring its failure (Dugan et al. 2003; Canals et al. 2004a).

Excess pore pressure $(\Delta \mathrm{u})$ can be estimated from the difference between the current vertical effective stress $\left(\sigma^{\prime}{ }_{\text {vo }}\right)$ and the preconsolidation pressure $\left(\sigma^{\prime}{ }_{p}\right)$ as expressed by:

$\Delta \mathrm{u}=\sigma_{\mathrm{vo}}^{\prime}-\sigma_{\mathrm{p}}$

The vertical effective stress $\sigma^{\prime}{ }_{\text {vo }}$ is defined as the difference between the total vertical stress $\left(\sigma_{\mathrm{vo}}\right)$ and the pore fluid pressure that, considering hydrostatic conditions $\left(\mathrm{u}_{\mathrm{h}}\right)$, is $\rho_{\mathrm{w}} \mathrm{gz}$. The preconsolidation pressure is the highest pressure the deposit (or soil) has ever been submitted. While it is normally interpreted on the basis of oedometer tests it can be also estimated from in situ tests. Laboratory oedometer consolidation tests are usually conducted on small samples assumed to be undisturbed. However, almost all recovered samples have some degree of disturbance (Grozic et al. 2003; Lunne et al. 2006) and, consequently, the laboratory-derived strength and consolidation parameters may not be entirely representative of the in situ soil conditions. In situ tests are performed under existing stresses and boundary conditions in the field, providing more accurate and reliable results than laboratory tests.

The piezocone test (CPTU) is now the most widely used in situ test for the geotechnical characterization of marine sediments in deepwater. CPTU involves the measurement of the resistance and friction of sediments to steady and continuous penetration of a piezocone penetrometer equipped with sensors for cone tip resistance $\left(q_{c}\right)$, sleeve friction $\left(f_{s}\right)$ and pore pressure $(u)$. These are the three direct CPTU parameters that are recorded continuously with depth during in situ CPTU testing. The near continuous information provided by CPTU direct and derived parameters, as the corrected cone resistance $\left(q_{t}\right)$, is utilized to predict the nature of subseafloor sedimentary sequences and geotechnical properties (Lunne et al. 1997). In particular, several empirical formulas allow determining the preconsolidation pressure based on piezocone measurements (Lunne et al. 1997). Some studies have shown the reliability of 
obtaining the preconsolidation pressure $\sigma_{\mathrm{p}}$ for a wide range of clays from the net tip resistance $\left(q_{n e t}\right)$ (see Appendix A) and the parameter $\mathrm{N}_{\sigma t}$, which relates the corrected cone resistance $q_{t}$ and the vertical effective stress $\sigma^{\prime}{ }_{\text {vo }}$ to the preconsolidation pressure $\sigma_{\mathrm{p}}$ (Demers and Leroueil 2002; see Appendix B).

This paper deals with the CPTU characterization of a $150 \mathrm{~m}$ thick sedimentary sequence from the upper continental slope in the Gulf of Lion, northwestern Mediterranean Sea. The aim of this work is to exploit preconsolidation pressure $\sigma^{\prime}{ }_{\mathrm{p}}$ data derived from in sit CPTU tests in order to establish the links between the stress history of such sedimentary sequence and the geological processes that determined its development. The study site was selected on the basis of high resolution seismic reflection data in the fluvial-dominated continental slope of the Gulf of Lion, which holds a continuous sediment record of at least the last $500 \mathrm{kyr}$ (PROMESS1 research project unpublished results; see Sections 2 and 3).

\section{Study area}

\subsection{Geological setting}

The Gulf of Lion passive continental margin includes the widest $(70 \mathrm{~km})$ continental shelf in the western Mediterranean Sea with the shelf edge at a mean depth of $135 \mathrm{~m}$. The continental slope is dissected by an intricate network of 100-150 km long submarine canyons feeding base-ofslope and rise thick sediment bodies such as the Rhône Deep Sea Fan and the Pyrenean Canyon Deep Sediment Body (Alonso et al. 1991; Berné et al. 1999; Canals 1985; Canals et al. 2004b; dos Reis 2005; Droz 1983; Medimap Group 2005). Canyon heads and upper courses are cut into the continental shelf and are separated by interfluves (or inter-canyon areas) that are assumed to hold the most continuous, high resolution sedimentary sequences of Quaternary age in the Gulf of Lion's slope. The main sediment source in the study area, accounting for shelf, slope and rise outbuilding, is the Rhône River, with minor inputs from other rivers along the shores of the Gulf of Lion (UNEP/MAP/MED POL 2003).

Outer shelf Quaternary sequences are characterized on seismic reflection profiles by alternating steep and low angle clinoforms that correspond, respectively, to high energy (sand) and low energy (silt) sediments formed during glacial and interglacial cycles (Aloisi 1986; Bassetti et al. 2006; Berné et al. 1999 and 2004; Jouet et al. 2006; Rabineau et al. 2005; Tesson et al. 2000). Such outer shelf clinoforms have been attributed to sandy shoreface and muddy offshore 
deposits, respectively (Berné and Gorini 2005), and related to $100 \mathrm{kyr}$ glacio-eustatic cycles (Rabineau et al. 2005). Seaward, along the upper slope interfluves, outer shelf erosional surfaces created during low stands of the sea become correlative conformities, shelf sequences get thicker due to higher accommodation space, and sediment grain size is finer. These fine-grained sedimentary sequences may destabilise under the influence of external triggers (Sultan et al. 2004 and 2006).

\subsection{Site description}

The drilling site PRGL1 was located at $42^{\circ} 41^{\prime} 23.30^{\prime \prime} \mathrm{N}$ and $003^{\circ} 50^{\prime} 15.50$ ' ' $\mathrm{E}$, at $298 \mathrm{~m}$ of water depth, on the uppermost part of the interfluve separating the Aude (or Bourcart) and Hérault submarine canyons, in the western half of the Gulf of Lion, 12 miles off the shelf edge that locally lies at $200 \mathrm{~m}$ depth (Fig. 1).

Preliminary chronostratigraphic and sedimentological data from borehole PRGL1_4 (Frigola et al. 2005; see Section 3 below) showed that the drill went through a Pleistocene sedimentary package made of silts and clays in variable proportions with some intercalated sand-bearing layers. Micropaleontological studies at this same site have revealed that the sand-bearing layers contain abundant coarse-grained planktic foraminifera and that they represent condensation levels (Sierro et al. 2005 and 2006). On the basis of seismic velocity analyses, the correlation between seismic reflection profiles crossing the PRGL1 site and borehole data suggests that the main seismic sequences, related to $100 \mathrm{kyr}$ cycles, are bounded by seismic amplitude anomalies caused by the above mentioned condensed layers (Berné et al. 2006).

\section{Materials and methods}

\subsection{Borehole information}

CPTU in situ testing and drilling of site PRGL1 were made from SRV Bavenit, operated by Fugro Engineers B.V., as part of the EC funded "PROfiles across MEditerranean Sedimentary Systems 1" (PROMESS1) research project. Five boreholes were drilled at site PRGL1 that were named PRGL1_1 to PRGL1_5. Of these, PRGL1_3, PRGL1_4 and PRGL1_5 have been used for this study (Table 1). CPTU measurements down to $150 \mathrm{mbsf}$ and in situ dissipation tests at four depths were performed in-hole at PRGL1_3. Following sediment coring, downhole logging was done at PRGL1_4 down to 301 mbsf. Sediment samples from PRGL1_4 have been 
analyzed for grain size and biostratigraphy. Continuous coring for geotechnical purposes was made at PRGL1_5 down to 126.4 mbsf with >95\% recovery (Table 1).

\subsection{In situ measurements}

The CPTU testing technique utilized in our study consists of pushing down the piezocone penetrometer from the seafloor to the targeted subseafloor depth by steps (each implying an individual CPTU test) within the drill hole. The pushing equipment was made of a downhole WISON CPT with a $3 \mathrm{~m}$ stroke downhole jacking unit and a thrust capacity of $90 \mathrm{kN}$. During testing, the WISON CPT is lowered by its umbilical wire to the drill bit level, where it seats and latches into the seating subassembly or seabed frame (Fig. 2a). The tool is then hydraulically pushed down at a constant rate of $2 \mathrm{~cm} \cdot \mathrm{s}^{-1}$. Upon reaching the maximum stroke of $3 \mathrm{~m}$ or the 90 $\mathrm{kN}$ thrust capacity, the test is finished and the system depressurized. Successive $3 \mathrm{~m}$ long tests allow completing the CPTU profile down to the target depth.

The piezocone penetrometer used in this study is a relatively small instrument with a diameter of $36 \mathrm{~mm}$, a cross-sectional area of $1000 \mathrm{~mm}^{2}, 60^{\circ}$ tip apex angle and a $13 \mathrm{~cm}$ sleeve (Fig. 2b). $q_{c}$ and $f_{s}$ (see Section 1 ) are measured on two electrical strain-gauge load cells located inside the sleeve (Fig. 2c). The piezocone penetrometer applied to our study uses a so-called subtraction load-cell arrangement, which allows measurements of the axial forces on the cone and the friction sleeve by compression of two internal strain-gauge load cells. The load cells are in series so that the lower load cell measures $q_{c}$ and the upper load cell measures $q_{c}$ and $f_{s}$. Therefore, $f_{s}$ is obtained by subtracting $q_{c}$ from the measure by the upper load cell. The pore pressure $u$ can be measured at different locations throughout the piezocone penetrometer: at the cone, $u_{1}$, behind the cone, $u_{2}$, and behind the sleeve friction sensor, $u_{3}$. Pore pressure measurements presented in this paper correspond to $u_{2}$ (Fig. $2 \mathrm{~b}$ ) as this location usually provides good stratigraphic detail and dissipation data (Lunne et al. 1997). $q_{c}, f_{s}$ and $u_{2}$ profiles run at PRGL1_3 borehole are shown in Figure 3.

In situ tests yielded preconsolidation pressure and excess pore pressure data. The direct relationship between the preconsolidation pressure $\sigma^{\prime}$, through the $\mathrm{N}_{\sigma \mathrm{t}}$ parameter (see Section 1 and Equation 5 in Appendix B) following Demers and Leroueil (2002), and the net tip resistance $q_{\text {net }}$, derived from the piezocone tests (see Equation 2 in Appendix A), provided the stress history of PRGL1 site. Continuous P-wave (Vp) measurements were performed by downhole logging at borehole PRGL1_4. The resulting data have been used for estimating a Vp 
based continuous excess pore pressure profile (see Appendix C). The equilibrium pore pressure has been estimated from in-hole dissipation tests at PRGL1_5 at 11.7, 32.6, 59.9 and 125.9 mbsf (see Appendix C; see Section 4.3 for details).

\subsection{Laboratory tests and age model}

Of the various laboratory geotechnical tests made on samples from PRGL1 (Sultan et al. 2007), we have used the results of six oedometer tests performed on PRGL1_5 samples (see Section 4.1). Time between load increments was 24 hours, the size of the cell $50 \mathrm{~mm}$ and the initial height of the sample $20 \mathrm{~mm}$. Oedometer tests were conducted according to the ASTM D-2435 method (ASTM 1993). Sand contents have been determined from bulk and carbonate free sediment fractions (BF and CFF, respectively) of 168 samples (Frigola et al. 2005; see Appendix A.2).

The coarse-grained planktic foraminifera and other sand-size particles, which compose the condensed layers, have been used to calibrate our record to global climatic records. This resulted in an inferred age model (Table 2) based on the assumption that coarse-grained condensed units formed at times of rapid sea level rises during global melt-water events, when sediment supply to the upper slope decreased suddenly as a consequence of the flooding of the continental shelf. These melt water events occurred in phase with the longest and warmest Greenland interstadials of the last $300 \mathrm{kyr}$ at least (Sierro et al. 2005 and 2006). Such an inferred age model (Table 2) is considered accurate enough for the purposes of this paper, and it has been used to calculate average sedimentation rates (Dennielou et al. 2006).

\subsection{Borehole-seismic data correlation}

The vertical positions of data from CPTU and laboratory analyses on seismic reflection profiles have been calculated using MSCL gamma-density shaped P-wave velocities calibrated by interval seismic velocity analysis from in situ measurements in order to convert the meter below sea floor (mbsf) scale from borehole measurements and coring into the millisecond two-way travel time (mstwtt) scale of the seismic reflection profiles. The seismic data were acquired during the "Marion" cruise in year 2000 aboard R/V "Le Suroît". A 24-channel, 300 m long high resolution streamer was used, together with a cluster of mini-GI and GI-guns. The seismic section used in this study corresponds to an amplitude processed multi-channel high-resolution seismic line. 


\section{Results}

\section{1. $\sigma_{\mathrm{p}}$ from laboratory tests}

Preconsolidation pressures $\sigma^{\prime}$ p obtained following Casagrande’s (1936) and Onitsuka's (in Grozic et al. 2003) methods (Figs. 4a and 4b) are shown in Table 3, where they are labelled $\sigma_{\text {pa }}$ and $\sigma_{\mathrm{pb}}^{\prime}$, respectively. Of these we give more relevance to $\sigma_{\mathrm{pb}}^{\prime}$ based on Onitsuka's method, which is easier to apply than the Casagrande's one (Grozic et al. 2003). Figure 4c shows oedometer results obtained from six PRGL1_5 samples (see Section 3.3) named, from shallower to deeper, S3, S8, S9, S14, S15 and S20. Calculated $\sigma_{\mathrm{pb}}{ }^{\prime}$ values increase with depth, from 90 $\mathrm{kPa}$ at $4.3 \mathrm{mbsf}$ (sample S3) to $198 \mathrm{kPa}$ at $45 \mathrm{mbsf}$ (sample S20) (Table 3).

\section{2. $\sigma_{\mathrm{p}}$ from piezocone measurements}

Following the approach described in Appendix B to calculate a continuous $\sigma^{\prime}$ p profile based on piezocone data, six $\mathrm{N}_{\sigma \mathrm{t}}$ points were calculated from $\sigma_{\mathrm{pb}}$, which are 3.4, 5.6, 6.9, 5.9, 4.6 and 4.5 for S3, S8, S9, S14, S15 and S20, respectively. These $\mathrm{N}_{\sigma \mathrm{t}}$ values combined with grain size distributions allow subdividing the sediment column into 9 intervals in a way that changes in $\mathrm{N}_{\sigma \mathrm{t}}$ relate to soil type changes (Table 4). $\mathrm{N}_{\sigma \mathrm{t}}$ values from $\sigma_{\mathrm{pb}}$ range from 3.4 to 6.9 (Table 4), which are consistent with those published by Lunne et al. (1997) and Demers and Leroueil (2002). $\mathrm{N}_{\sigma \mathrm{t}}$ values in Table 4 have been used to calculate a continuous $\sigma^{\prime}$ p profile (Fig. 5) based on Equation [5] of Appendix B.

Figure 5a shows $\sigma^{\prime}$ p profiles obtained from the approach based on the site-specific $\mathrm{N}_{\sigma \mathrm{t}}$ (black line) and the constant $\mathrm{N}_{\sigma \mathrm{t}}=3.4$ (grey line) following Demers and Leroueil (2002). $\sigma_{\mathrm{pb}}{ }^{\prime}$ values from the oedometer tests are also plotted (red circles). By relating $\sigma_{\mathrm{p}}$, to the vertical effective stress, $\sigma^{\prime}$ vo, we find clear overconsolidation from the surface down to $9 \mathrm{mbsf}$, and a slight overconsolidation down to $12 \mathrm{mbsf}$ if considering the site-specific $\mathrm{N}_{\sigma \mathrm{t}}$ and down to $30 \mathrm{mbsf}$ if $\mathrm{N}_{\sigma \mathrm{t}}=3.4$ (Fig. 5b). Below these depths the sequence appears underconsolidated according to $\sigma_{\text {vo }}^{\prime}>\sigma_{\mathrm{p}}^{\prime}$ (see Equation 4 in Appendix B).

The identification of overconsolidation in the upper $30 \mathrm{~m}$ indicates that $\sigma^{\prime}{ }_{p}$ calculated from $\mathrm{N}_{\sigma \mathrm{t}}$ = 3.4 following Demers and Leroueil (2002) cannot be applied to our case since the erosion processes required to generate such an overconsolidation have ever been described in the study 
area. Therefore, we consider the $\sigma^{\prime}{ }_{p}$ based on the site-specific $N_{\sigma t}$ to be the best approach for the upper continental slope in the Gulf of Lion.

\subsection{Overpressure}

Underconsolidation at site PRGL1 is explained by excess pore pressure (Fig. 5c). According to Equation [6] in Appendix C.1, the excess pore pressure calculated following the site-specific $\mathrm{N}_{\sigma \mathrm{t}}$ approach indicates that the soil is overpressurized below $12 \mathrm{mbsf}$ down to the borehole bottom. In order to verify this overpressure, labelled $\Delta \mathrm{u}_{\mathrm{CPTU}}$, we compared it to an $\Delta \mathrm{u}$ profile estimated from P-wave velocity downhole logging measurements at borehole PRGL1_4, $\Delta \mathrm{u}_{\mathrm{LOGS}}$, following Equations [7] to [9] of Appendix C.1. The average values used for this calculation are $\mathrm{e}_{0}=1.21$ and $\lambda=0.09$ (see Appendix C.1).

The $\Delta \mathrm{u}_{\text {LOGS }}$ profile depicts only three overpressurized intervals at 34-39, 89.5-91.5 and 121.7122.5 mbsf (red curve in Fig. 6). Additional equilibrium pore pressure values, $\Delta \mathrm{u}_{\mathrm{e}}$, obtained from dissipation tests (Figs. 7a to 7c) are compared with consistent $\Delta \mathrm{u}_{\mathrm{CPTU}}$ and $\Delta \mathrm{u}$ values derived from oedometer results, $\Delta \mathrm{u}_{\text {oedo }}$ (calculated by means of Equation 6 in Appendix C.1). Of the three levels with excess pore pressure identified from $\Delta \mathrm{u}_{\mathrm{LOGS}}$ only the one at 34-39 mbsf clearly corresponds to a relative increase in $\Delta \mathrm{u}_{\mathrm{CPTU}}$ and in the sand fraction from 34 to $36 \mathrm{mbsf}$ (Figs. 6 and 8). The 121.7-122.5 mbsf interval is at the boundary of a sand fraction increase (Fig. 8). In consequence, as it appears that $\Delta \mathrm{u}_{\mathrm{LOGS}}$ is not consistent with $\Delta \mathrm{u}_{\text {oedo }}$ and $\Delta \mathrm{u}_{\mathrm{e}}$, and since no relationship can be established with the general trend of $\Delta \mathrm{u}_{\mathrm{LOGS}}$ and grain size, we have decided to discard $\Delta \mathrm{u}_{\text {LOGs. }}$. Table 5 summarizes $\Delta \mathrm{u}$ values as derived from oedometer and dissipation tests.

Down to $12 \mathrm{mbsf}$ the adimensional ratio of the overpressure magnitude $\lambda^{*}$ (Fig. 6; see Appendix C.1) responds to $\sigma_{p}{ }_{p}<\sigma^{\prime}$ vo (Fig. 5a and 5b) and, thus, to the presence of overpressure. Below this depth $\lambda^{*}$ allows differentiating two main units: (i) from 12 to 72 mbsf, characterized by variable $\lambda^{*}$ with predominance of $\lambda^{*}>0.3$, and (ii) a lower unit from $72 \mathrm{mbsf}$ to the borehole base at 150 mbsf, with $\lambda^{*} \sim 0.3$ (Fig. 6). The boundary at 72 mbsf coincides with a clear decrease in the sand content in both the bulk (BF) and the carbonate free fractions (CFF) (Fig. 8). The unit from 12 to 72 mbsf contains average sand contents of $1.8 \%$ (BF) and 2.8\% (CFF), with maximum values of $11.80 \%(\mathrm{BF})$ and $5.96 \%$ (CFF), whereas in the lower unit the averages are $0.44 \%(\mathrm{BF})$ and 1.5\% (CFF), with maximum values of 2.36\% (BF) and 8.91\% (CFF) (Fig. 8). From this, we 
infer that small augmentations in the sand content may lead to significantly higher overpressures (higher $\lambda^{*}$ ).

The lower and upper bound shear strength ( $\mathrm{Su}_{\min }$ and $\mathrm{Su}_{\max }$, respectively) were calculated from the net tip resistance $q_{\text {net }}$ and the factor $\mathrm{N}_{\mathrm{k}}$ equal to 15 and 10, respectively (Appendix C.2). $\mathrm{Su}_{\min }, \mathrm{Su}_{\max }$ and in situ shear vane measurements published in Sultan et al. (2007) were used for calculating the Shansep factor $\alpha_{\mathrm{s}}$ (Fig. 9). This factor allows the evaluation of the consolidation by normalizing the shear strength Su with respect to effective vertical stress $\sigma^{\prime}{ }_{v 0}$. Values lower than 0.25 indicate underconsolidation and upper values overconsolidation (Tanaka et al. 2002). $\alpha_{s}$ values of in situ vane measurements and $\mathrm{Su}_{\min }$ obtained at PRGL1 are lower than 0.25, which confirms the presence of underconsolidation below 9 and 20 mbsf, respectively. This indicates that overpressurized sediments appear at some depth between 9 and 20 mbsf, which is in agreement with our boundary between overconsolidated and underconsolidated sediments at 12 mbsf.

\section{Discussion}

\subsection{Stress history related to geological processes}

In our PRGL1 site we have found both overconsolidated sediments in the upper $12 \mathrm{~m}$ and underconsolidated sediments below. Overconsolidation in marine sediments has been related to erosion and to ice sheet degrounding resulting in the removal of overburden pressure (Craig 2005). While overconsolidation in the study area cannot be attributed to ice sheet dynamics (Lowe and Walker 1984), no evidences of erosion have been found in the PRGL1 site (Berné et al. 2004). Therefore, other mechanisms should account for the overconsolidation of the uppermost section of PRGL1. One acceptable hypothesis is the ageing effects related to cementation, bioturbation and physico-chemical changes that have been described in marine environments (Baraza et al. 1990; Mitchell 1976; Poulos 1998; Silva and Bryant 2000; Sultan et al. 2000).

On the other hand, underconsolidation of marine sediments is usually associated with excess

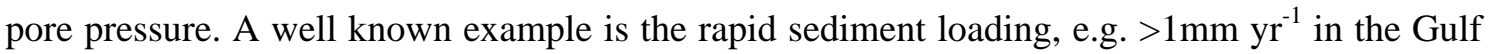
of Mexico (Expedition 308 Scientists, 2005), that favours overpressure development in the sediment column as fast burial by fine sediment fluxes prevents fluids to escape. The fluids thus 
bear some of the overburden pressure and delay the normal consolidation process, which leads to underconsolidation (Gordon and Flemings 1998).

We have estimated by back analysis the excess pore pressure generated by sediment loading $\left(\Delta \mathrm{u}_{\mathrm{s}}\right)$ and the stress state at PRGL1 (see Appendix C.1 for the details on the procedure followed). Our results suggest that the averaged sedimentation rates at PRGL1 site (Table 6) are not high enough to generate the required overpressure, i.e. $\Delta \mathrm{u}_{\mathrm{s}}$ only explains $\sim 1 \%$ of the total excess pore pressure found in the study area (Fig. 6).

Other sources of excess pore pressure reported in the literature are gas hydrates (Jansen et al. 1987), and the decomposition of the organic matter that can result in the generation of free gas and thus excess pore pressure (Orange et al. 2005). However, temperature and pressure conditions prevent the development of gas hydrates in the study area (Kvenvolden 2000). Excess pore pressures may be also triggered by earthquakes, as found in the Norwegian continental margin (Solheim et al. 2005), but the study area is seismically quiet (Grüntal et al. 1999).

The presence of pockmarks in the study area, with a large one extending deep into the sedimentary column at the location of PRGL1, and of high amplitude values in seismic reflection profiles (Berné et al. 2006 and our Fig. 8) suggest the presence of free gas that could account for the generation of the observed excess pore pressure.

It is known that overpressure may appear in sand-bearing layers interbedded within low permeability sediment packages preventing fluids to escape (Magara 1978.). The PRGL1 $\lambda^{*}$ profile displays quasi-constant low overpressure values $\left(\lambda^{*} \sim 0.3\right)$ at the lower unit, from $72 \mathrm{mbsf}$ to the borehole base, and higher values $\left(\lambda^{*}>0.3\right)$ along most of the unit above, from 72 to 12 mbsf. We associate this specific overpressure profile to four overpressure sources, SI to SIV from bottom to top, with $\lambda^{*}>0.3$, that correspond to depth levels where the dominantly siltyclayey sediment contains increased proportions of sand (Fig. 8).

Seismic reflection profiles crossing the PRGL1 site show high amplitudes at the depths of overpressure sources SI, SII, SIII and SIV that could indicate (i) overpressure due to the presence of free gas and/or (ii) low P-wave velocity also generated by the presence of free gas (highest seismic amplitudes in Fig. 8). These depth levels show relatively high sand contents (mainly in the CFF) and are characterized by an increased cone resistance $\left(q_{c}\right)$ and a reduced 
pore pressure $\left(u_{2}\right)$ (Fig. 10) due to the permeability of sand. Other levels displaying similar sand contents do not show equivalent high amplitudes in the seismic reflection profiles. Some disrupted reflectors from 150 mbsf to the seafloor in the seismic reflection profile of Figure 8 indicate vertical fluid migration, likely of free gas. This observation supports the existence of a link between overpressure and free gas from SI upwards, as related to the pockmark in the seismic reflection profile in Figure 8.

The convex shape of the $\lambda *$ profile from 33 to 72 mbsf suggests that fluid flow and overpressure generation from SII and SIII occurs in all directions whereas from SIV only upwards fluid migration is possible due to $\lambda^{*}<0.3$ values likely related to a relative low permeability layer from 27 to 33 mbsf.

The excess pore pressure related to free gas could be explained by gas exsolution processes and sea level variations driven by global climate oscillations. Sea level falls cause a reduction in hydrostatic pore pressure that lowers the gas solubility and results in gas exsolution. The exsoluted gas will then accumulate preferentially in relatively more porous (i.e. sand-bearing) layers interbedded within less permeable (i.e. without sand) layers. In contrast, during sea level rises, the increase in the hydrostatic pressure dissolves free gas in the water would therefore decrease the excess pore pressure. According to this, the four main sources of overpressure (SI to SIV) found in sand-bearing layers could be linked to millennial scale sea level changes and gas exsolution.

\subsection{Overpressure and sea level variations}

In Figure 11, we compare sand contents (BF and CFF), depth of main overpressure sources and the sea level curve of Sidall et al. (2003). The 150 meters long sedimentary sequence described in this paper represents about $340 \mathrm{kyr}$ (336 kyr at 159.98 mbsf as shown in Table 2) during which overall decreasing sea level fall periods occupy a much longer cumulative time period than sea level rises.

Our inferred age model (Table 2) allows assigning ages to the main overpressured layers. The age of SIV is 24-26 kyr old, SIII is 33-38 kyr old, SII is 46-55 kyr old, and SI is 220-238 kyr old. According to the general sea level curve in Figure 11, SIV and SIII correspond to relatively high stillstands, SII to the highstand part of a secondary rise and fall event, and SI to a high sea level followed by a pronounced lowering. Therefore, though SIV, SIII and SII occurred during 
the decreasing sea level falling trend from 123 to $20 \mathrm{kyr}$, they all represent intervals of relatively high sea level preceding lowering phases.

The aforementioned suggests that sand-bearing intervals SI to SIV were deposited under relative highstands and subsequent sea level falls might generate excess pore pressure by gas exsolution. Therefore, the overpressure source SI would relate to the sea level peak and fall from 238 to $220 \mathrm{kyr}$, to the dissolution period from 220 to $193 \mathrm{kyr}$ and to a first exsolution period from 193 to $130 \mathrm{kyr}$, and to a later dissolution period from 130 to $123 \mathrm{kyr}$ and a second exsolution period during the general sea level fall from 123 to 20 kyr (Fig. 11). Overpressure source SII would be linked to the decrease in sea level from 50 to $38 \mathrm{kyr}, 33$ to $26 \mathrm{kyr}$ and 24 to $20 \mathrm{kyr}$, SIII to the decrease from 33 to 26 and 24 to $20 \mathrm{kyr}$, and SIV to the decrease from 24 to $20 \mathrm{kyr}$, in agreement with the findings of Jouet et al. (2006) in the same area.

The highest excess pore pressure is to be expected at level SI as the dissipation of the excess pore pressure is proportional to the square of the drainage distance that in this case is the distance to the seafloor. Therefore, for the same initial excess pore pressure, SIV would dissipate the excess pore pressure much earlier than SI. However, successive phases of exsolution and dissolution (during sea level rises) would explain lower $\lambda^{*}$ values for SI. Compared to SI, the different history of SII to SIV, which have been affected by only one major sea level rise (the one following the last deglaciation from $20 \mathrm{kyr}$ to present), would explain the higher excess pore pressure found above 72 mbsf (Fig. 8). Indeed, this particular depth coincides with the highstand at $123 \mathrm{kyr}$, supporting the idea that gas in layers below $72 \mathrm{mbsf}$ was significantly affected by dissolution processes from 130 to 123 kyr. An additional relevant factor that may justify the higher excess pore pressures at the upper levels SII to SIV with respect to SI is the volume change of free gas due to a decrease of the hydrostatic pressure: for a given decrease of the hydrostatic pressure $\Delta \mathrm{u}_{\mathrm{h}}$, the volume change of the free gas (or the excess pore pressure) decreases with depth as it depends on $\Delta \mathrm{u}_{\mathrm{h}} / \mathrm{u}_{\mathrm{h}}{ }^{2}$ where $\mathrm{u}_{\mathrm{h}}$ is the hydrostatic pressure at a given depth.

The excess pore pressure generated by gas exsolution is considered to take place during the whole sea level fall process. Therefore the excess pore generated by gas release and exsolution from sandy layers could be considered as a continuous flow during the whole sea level fall process (Appendix D.1). By considering the level SI and for a mean of the hydraulic diffusivity $\mathrm{D}_{\mathrm{h}}$ of $5.10^{-9} \mathrm{~m}^{2} / \mathrm{s}$ (determined from oedometer tests), the dissipation of $93 \%$ of the pressure will 
need around $\mathrm{t}_{93 \%}=3960$ years for a drainage distance of $25 \mathrm{~m}$ and $t_{93 \%}=90000$ years for a drainage distance of $120 \mathrm{~m}$.

A simple calculation was also carried out to evaluate the time needed for the dissipation process of the pore pressure during the last sea level rise for the whole sedimentary profile (Appendix D.2). Three $\lambda^{*}$ profiles at $20 \mathrm{kyr}, 10 \mathrm{kyr}$ and $0 \mathrm{kyr}$ were calculated and are presented in Figure 12a. For the considered sediment profile with the hydraulic diffusivities values presented in Figure 12b, it is clear that $20 \mathrm{kyr}$ is not enough to dissipate the excess pore pressure generated by gas exsolution.

It is not known how fast gas exsolution responds to decreases in the hydrostatic pressure during sea level falls, nor how fast dissolution increased under the high hydrostatic pressure of both the 123-116 kyr highstand interval and the present-day highstand. Notwithstanding, we think likely that part of the present day excess pore pressure corresponds to the pore pressure generated during previous sea level falls and lowstands. The inherited excess pore pressure possibly is proportional to the cumulated time difference between slow, punctuated sea level falls and much faster sea level rises (Fig. 11). Gas exsolution during sea level falls increases the gas saturation and generates upward migration of the free gas. Shallower layers are, therefore, submitted to local gas exsolution but also to the migration of deep overpressured gas. The migration of the free gas is proportional to the time length of sea level falls. During the quick sea level rises (Fig. 11), residual excess pore pressure may exist as migrated gas partially saturating shallower sandbearing layers exceeds gas solubility under the new hydrostatic conditions induced by high sea level. The presence of pockmarks in the study area is a clear indication of the significance of gas migration, which occurred mainly during sea level falls.

\section{Conclusions}

The stress history at PRGL1 site has been reconstructed from empirical correlations based on CPTU measurements and derived preconsolidation pressures, which are consistent with results from oedometer tests and dissipation tests. By relating the CPTU based preconsolidation pressure and the current vertical effective stress, an excess pore pressure has been found from 12 mbsf down to the borehole bottom at 150 mbsf. Our data show that such an excess pore pressure is mainly fed by four overpressure sources corresponding to sand-bearing layers within an upward gas migration setting related to pockmark development. We link the observed overpressure situation to persistent hydrostatic pressure diminutions causing gas exsolution 
during the prolonged periods of sea level lowering of, at least, the last 340 kyr. No other overpressure sources have been identified in the study area. Our results clearly point out the need of further studies on the effects of global sea level changes coupled with the presence and behaviour of gas to elucidate the stress history of continental slopes, where most of submarine instability processes occur worldwide. In situ measurements, like CPTU, are crucial to address this question.

\section{Acknowledgements}

We thank the PROMESS1 scientific party, and the technical staff and crew from Fugro Engineers B.V. and Amige onboard SRV Bavenit (ref. EVR1-CT-2002-40024) for their continuous support during CPTU tests at sea. The EURODOM Research Training Network (ref. RTN2-2001-00281) eased the cooperation between IFREMER and University of Barcelona researchers. Additional support was provided to Ifremer staff by the French Agence Nationale de la Recherche (ANR, contract NT05-3-42040). The crew and technical staff onboard R/V Le Suroît (Ifremer and Genavir) are thanked for their assistance during seismic reflection data acquisition at sea. We also thank G. Herrera (Universitat de Barcelona) for grain size analyses and E. Thereau (Ifremer) for processing the seismic data. Dr. J. Locat and Dr. S. Leroueil from the University of Laval, Quebec, provided helpful suggestions. We also acknowledge all other researchers and technicians from PROMESS1 partner institutions that have contributed in different ways to this research. S. Lafuerza benefits from a $\mathrm{PhD}$ research grant by the Spanish Ministry for Education and Science. GRC Geociències Marines is funded by Generalitat de Catalunya research grants program to high quality scientific groups (ref. 2005 SGR-00152).

\section{References}

Aloïsi JC (1986) Sur un modèle de sédimentation deltaïque: contribution à la connaissance des marges passives. Unpublished Doctorate Thesis, University of Perpignan, pp 162.

Alonso B, Canals M, Got H and Maldonado A (1991) Seavalleys and related depositional systems in the Catalan Sea (northwestern Mediterranean Sea). AAPG Bull 75: 1195-1214.

ASTM (1993) Standard Test Method for One-Dimensional Consolidation Properties of Soils. Annual Book of ASTM Standards, D2435-90, Vol. 04-08, pp 313-323. 
Baraza J, Lee H, Kayen, RE and Hampton MA (1990) Geotechnical characteristics and slope stability on the Ebro margin, western Mediterranean. Mar Geol 95: 379-393.

Bassetti MA, Jouet G, Dufois F, Berné S, Rabineau M and Taviani M (2006) Sand bodies at the shelf edge in the Gulf of Lions (Western Mediterranean): Deglacial history and modern processes. Mar Geol 234: 93-109.

Berné S, Loubrieu B and Calmar Shipboard party (1999) Canyons and recent sedimentary processes on the western Gulf of Lions margin. First results of the Calmar cruise. C R Acad Sci Paris 328: 471-477.

Berné S, Carré D, Loubrieu B, Mazé JP and Normand A (2001) Carte morphobatimétrique du Golfe du Lion à l'échelle 1/100000 ${ }^{\text {ème }}$. IFREMER et Région Languedoc Roussillon Brest.

Berné S, Rabineau M, Flores, JA and Sierro FJ (2004) The Impact of Quaternary global changes on strata formation, exploration of the shelf edge in the northwest Mediterranean Sea. Oceanography 17 (4): 92-117.

Berné S and Gorini C (2005) The Gulf of Lions: An overview of recent studies within the ‘French Margins’ programme. Mar Pet Geol 22 (6-7): 691-693.

Berné S, Jouët G, Alix AS, Bassetti MA, Canals M, Cattaneo A, Colmenero H, Dennielou B, Floch G, Frigola J, Frumoltz N, Flores JA, Gelfort R, Gravalosa J, Rabineau M, Ridente D, Schneider R, Schoolmester T, Sierro F, Sultan N, Taviani M, Thereau ET, Tulloch G, Thouveny $\mathrm{N}$ and Wallrabe-Adams HJ (2006) Integrating seismic and core data at PRGL1 and PRGL2 Promess drillsites, a first attempt. Geophys Res Abstr EGU06-A-02282.

Bolton AJ, Maltman AJ and Clenell MB (1998) The importance of overpressure timing and permeability evolution in fine-grained sediments undergoing shear. J Struct Geol 20 (8): 10131022.

Canals M (1985) Estructura sedimentaria y evolución morfológica del talud y el glacis continentales del Golfo de León: Fenómenos de desestabilización de la cobertura cuaternaria. PhD Thesis University of Barcelona Barcelona, pp 618. 
Canals M, Lastras G, Urgeles R, Casamor JL, Mienert J, Cattaneo A, De Batist M, Haflidason H, Imbo Y, Laberg JS, Locat J, Long D, Longva O, Masson DG, Sultan N, Trincardi F and Bryn P (2004a) Slope failure dynamics and impacts from seafloor and shallow sub-seafloor geophysical data: case studies from the COSTA Project. Mar Geol 213: 9-72.

Canals M, Casamor JL, Lastras G, Monaco A, Acosta J, Berné S, Loubrieu S, Weaver PPE, Grehan A and Dennielou B (2004b) The role of canyons on strata formation. Oceanogr 17 (4): 80-91.

Casagrande A (1936) The determination of the pre-consolidation load and its practical significance. In Proceedings of the 1st International Soil Mechanics and Foundation Engineering Conference, Cambridge, Mass., 22-26 June 1936. Edited by A. Casagrande. Graduate School of Engineering, Harvard University, Cambridge, Mass. Vol. 3, pp. 60-64.

Craig R F (2005) Craig’s soil mechanics. $7^{\text {th }}$ Edition, Spon Press Cornwall, pp 447.

Demers D and Leroueil S (2002) Evaluation of preconsolidation pressure and the overconsolidation ratio from piezocone tests of clay deposits in Quebec. Can Geotech J 39: 174192.

Dennielou B, Sultan N, Sierro F, Gelfort R, Berné S and the Promess1 shipboard party (2006) The impact of sediment compaction on the calculation of the sedimentation rates and sedimentary fluxes based on physical and geotechnical properties from Promess1 borehole PRGL1 (Gulf of Lions, Western Mediterranean). Geophys Res Abstr EGU06-A-07986.

dos Reis T, Gorini C and Mauffret A (2005) Implications of salt-sediment interactions on the architecture of the Gulf of Lions deep-water sedimentary systems-western Mediterranean Sea. Mar Petrol Geol 22: 713-746.

Droz L (1983) L’éventail sous-marin profond du Rhône (Golfe du Lion): grands traits morphologiques et structure semi-profonde. PhD Thesis, Université de Paris VI Paris, pp 195.

Dugan B, Flemings P, Olgaard DL and Gooch MJ (2003) Consolidation, effective stress, and fluid pressure of sediments from ODP Site 1073, US mid-Atlantic continental slope. Earth Planet Sc Lett 215: 13-26. 
Expedition 308 Scientists (2005) Overpressure and fluid flow processes in the deep water Gulf of Mexico: slope stability, seeps and shallow-water flow. IODP Prel Rept 308 DOI: 10:2204/iodp.

Frigola J, Canals M, Berné S, Cacho I, Herrera G, Dennielou B, Gelfort R, Alix AS, Bassetti MA and Scientific Party (2005) Preliminary sedimentological and geochemical results from borehole GL1-4 in the North Western Mediterranean Sea, project PROMESS 1. Geophys Res Abstr EGU05-A-08590.

Gordon DS and Flemings PB (1998) Generation of overpressure and compaction-driven fluid flow in Plio-Pleistocene growth-faulted basin, Eugene Island 330, offshore Louisiana. Basin Res 10: 177-196.

Grozic JLH, Lunne T and Pande S (2003) An oedometer test study on the preconsolidation stress of glaciomarine clays. Can Geotech J 40: 857-872.

Jansen E, Befring S, Bugge T, Holtedahl H and Sejrup HP (1987) Large submarine slides on the Norwegian continental margin: sediments, transport and timing. Mar Geol 78: 77-107.

Jouet G, Berné S, Rabineau M, Bassetti MA, Bernier P, Dennielou B, Flores JA, Sierro FJ and Taviani M (2006) Shoreface migrations at the shelf edge and sea-level changes around the last glacial maximum (Gulf of Lions, NW Mediterranean). Mar Geol 234: 21-42.

Konert M and Vandenberghe J (1997) Comparison of laser grain size analysis with pipette and sieve analysis: a solution for the underestimation of the clay fraction. Sedimentology 44: 523535.

Kvenvolden KA (2000) Gas hydrate and humans. Ann Ny Acad Sci 912: 17-22. DOI: 10.1111/j.1749-6632.2000.tb06755.x.

Lowe JJ and Walker MJ (1984) Reconstructing Quaternary environments. Ed. Longman New York, pp 389. 
Lunne T, Robertson PK and Powell JJM (1997) Cone Penetration Testing in geotechnical practice. Blackie Academic/EF Spon, Rutledge Publishing Company, pp 312.

Lunne T, Berre T, Andersen KH, Strandvik S and Sjurse M (2006) Effects of sample disturbance and consolidation procedures on measured shear strength of soft marine Norwegian clays. Can Geotech J 43: 726-750.

Magara K (1978) Compaction and fluid migration. Practical petroleum geology. Developments in Petroleum Science 9, Elsevier Amsterdam, pp 319.

McCave IN, Manighetti B and Robinson G (1995) Sortable silt and fine sediment size/composition slicing: parameters for paleocurrent speed and paleoceanography. Paleoceanography 10 (3): 593-610.

Medimap Group (2005) Morpho-bathymetry of the Mediterranean Sea. CIESM/IFREMER special publication, Atlases and Maps, two maps at 1/2 000000.

Mitchell JK (1976) Fundamentals of soil behaviour. John Wiley \& Sons, Inc. New York, pp 422.

Nafe JE and Drake C (1957) Variation with depth in shallow and deep water marine sediments of porosity, density and the velocities of compressional and shear waves. Geophysics 22 (3): 523-552.

Orange D, García-García A, Lorenson T, Nittrouer CT, Miserocchi S, Langone L, Correggiari A and Trincardi F (2005) Shallow gas and flood deposition on the Po Delta. Mar Geol 222-223: 159-177.

Paillard D, Labeyrie L and Yiou P (1996) MacIntosh program performs time-series analysis. Eos 77: 379.

Poulos HG (1998) Marine Geotechnics. Unwin Hyman Ltd. London, pp 473. 
Rabineau M, Berné S, Aslanian D, Olive JL, Joseph P, Guillocheau F, Bourillet JF, Ledrezen E and Granjeon D (2005) Sedimentary sequences in the Gulf of Lion: A record of 100,000 years climatic cycles. Mar Petrol Geol 22: 775-804.

Sidall M, Rohling EJ, Almogi-Labin A, Hembleben Ch, Meischner D, Schmelzer I and Smeed DA (2003) Sea level fluctuations during the last glacial cycle. Nature 423: 853-858.

Sierro FJ, Hodell DA, Curtis JH, Flores JA, Reguera I, Colmenero-Hidalgo E, Bárcena MA, Grimalt JO, Cacho I, Frigola J and Canals M (2005) Impact of iceberg melting on Mediterranean thermohaline circulation during Heinrich events. Paleoceanography 20 (2). PA2019 DOI:10.1029/2004PA001051.

Sierro FJ, Flores JA, Pérez-Folgado M, González-Mora B, Bárcena MA, Dennielou B and Berné S (2006) Condensed layers and sea level changes in the Gulf of Lions during the last climatic cycles (data from Promess1, borehole PRGL1-4). Geophys Res Abstr EGU06-A09028.

Silva A and Bryant WR (2000) Jumbo piston coring in deep water Gulf of Mexico for seabed geohazard and geotechnical investigations. Proc 10th Int Offshore Polar Eng Conf Seattle 1: 424-433.

Solheim A, Berg K, Forsberg K and Bryn P (2005) The Storegga Slide complex: repetitive large scale sliding with similar cause and development. Mar Petrol Geol 22: 97-107.

Sultan N, Cochonat P, Dennielou B, Bourillet JF, Savoye B and Colliat JL (2000) Surconsolidation apparente et pression osmotique dans un sédiment marine. Earth Planet Sc Lett 331: 379-386.

Sultan N, Cochonat P, Canals M, Cattaneo A, Dennielou B, Haflidason Laberg JS, Long D, Mienert J, Trincardi F, Urgeles R, Vorren TO and Wilson C (2004) Triggering mechanisms of slope instability process and sediment failures on continental margins: a geotechnical approach. Mar Geol 213: 291-321.

Sultan N, Gaudin M, Berné S, Canals M, Urgeles R and Lafuerza S (2007) Analysis of slope failures in submarine canyon heads: An example from the Gulf of Lions. J Geophys Res 112 
F01009 DOI:10.1029/2005JF000408.

Tanaka H, Ritoh F and Omukai N (2002) Quality of samples retrieved from great depth and its influence on consolidation properties. Can Geotech J 39: 1288-1301.

Taylor D W (1948) Fundamentals of Soil Mechanics, Wiley, New York pp. 700.

Terzaghi K (1943) Theoretical Soil Mechanics, Wiley, New York pp. 528.

Tesson M, Posamentier HW and Gensous B (2000) Stratigraphic organization of Late Pleistocene deposits of the western part of the Rhone shelf (Languedoc shelf) from high resolution seismic and core data. AAPG Bull 84(1): 119-150.

UNEP/MAP/MED POL (2003) Riverine transport of water, sediments and pollutants to the Mediterranean Sea. MAP Technical Report series, 141, UNEP/MAP Athens pp 111.

Wyllie MRJ, Gregory AR and Gardner LW (1956) Elastic wave velocities in heterogeneous and porous media. Geophysics 21 (1): 41-70. 


\section{Table captions}

Table 1. PRGL1 site boreholes general information.

Table 2. Inferred age model for PRGL1_4 borehole obtained with the AnalySeries Version 1.1 (Paillard et al., 1996) on the basis of a preliminary age model from Sierro et al. (2006). Values have been rounded to the first decimal wherever needed. See details in main text Section 3.3.

Table 3. Preconsolidation pressure from oedometer tests as derived from Casagrande’s $\left(\sigma_{\mathrm{pa}}\right)$ and Onitsuka’s $\left(\sigma_{\mathrm{pb}}{ }^{\prime}\right)$ methods, respectively.

Table 4. Interval values of the site-specific $\mathrm{N}_{\sigma \mathrm{t}}$ compared to averaged grain size data. BF: bulk sediment fraction. CFF: carbonate free sediment fraction. Note that the sand and silt fractions are higher in the carbonate free subsamples than in the bulk samples for all intervals.

Table 5. Excess pore pressure obtained from oedometer tests $\left(\Delta \mathrm{u}_{\text {oedo }}\right)$ and equilibrium pore pressure from dissipation tests $\left(\Delta \mathrm{u}_{\mathrm{e}}\right)$.

Table 6. Corrected sedimentation rates and correction factors $(\alpha)$ applied. The values in the second, third and fourth columns have been rounded to the first, second and first decimal, respectively. 
Table 1

\begin{tabular}{|c|c|c|c|}
\hline Borehole & Performance & $\begin{array}{l}\text { Water depth } \\
\text { (mbsf) }\end{array}$ & $\begin{array}{l}\text { Borehole depth } \\
\text { (m) }\end{array}$ \\
\hline PRGL1_3 & CPTU (Dissipation tests at 11.7, 32.6, 59.9 and $125.9 \mathrm{mbsf}$ ) & 298 & 150.0 \\
\hline PRGL1_4 & Sedimentological sampling and downhole logging & 298 & 301.0 \\
\hline PRGL1_5 & Geotechnical sampling & 298 & 126.4 \\
\hline
\end{tabular}




\section{Table 2}

\begin{tabular}{ll}
\hline $\begin{array}{l}\text { Depth } \\
\text { (mbsf) }\end{array}$ & $\begin{array}{l}\text { Age } \\
\text { (kyr)* }\end{array}$ \\
\hline 0.1 & 14.5 \\
6.6 & 17.5 \\
21.0 & 24.0 \\
29.6 & 29.0 \\
31.5 & 30.6 \\
35.7 & 35.3 \\
36.7 & 38.4 \\
42.3 & 42.6 \\
44.6 & 45.5 \\
47.5 & 47.2 \\
49.6 & 52.1 \\
53.6 & 58.2 \\
58.6 & 61.9 \\
64.4 & 68.6 \\
65.2 & 73.0 \\
65.4 & 82.0 \\
68.4 & 102.0 \\
72.0 & 125.0 \\
117.6 & 198.0 \\
123.5 & 221.0 \\
127.5 & 243.0 \\
160.0 & 336.0 \\
\hline
\end{tabular}


Table 3

\begin{tabular}{clll}
\hline $\begin{array}{c}\text { Depth } \\
\text { (mbsf) }\end{array}$ & Sample & $\begin{array}{l}\sigma_{\mathbf{p a}}^{\prime} \\
(\mathbf{k P a})\end{array}$ & $\begin{array}{l}\sigma_{\mathbf{p b}}^{\prime} \\
(\mathbf{k P a})\end{array}$ \\
\hline 4.3 & $\mathrm{~S} 3$ & 90 & 90 \\
12.2 & $\mathrm{~S} 8$ & 60 & 80 \\
16.8 & $\mathrm{~S} 9$ & 80 & 110 \\
32.6 & $\mathrm{~S} 14$ & 215 & 167 \\
36.0 & $\mathrm{~S} 15$ & 156 & 176 \\
45.0 & $\mathrm{~S} 20$ & 125 & 198 \\
\hline
\end{tabular}




\section{Table 4}

\begin{tabular}{|c|c|c|c|c|c|c|c|c|c|}
\hline \multirow{2}{*}{$\begin{array}{l}\text { Depth } \\
\text { (mbsf) }\end{array}$} & \multirow{2}{*}{$\begin{array}{l}N_{\sigma t} \\
\text { (for } O_{C R} \text { ) }\end{array}$} & \multicolumn{2}{|c|}{ Sand (\%) } & \multicolumn{2}{|c|}{ Silt (\%) } & \multicolumn{2}{|c|}{ Clay (\%) } & \multicolumn{2}{|c|}{ Silt/Clay } \\
\hline & & $\mathrm{BF}$ & CFF & $\mathrm{BF}$ & CFF & $\mathrm{BF}$ & CFF & $\mathrm{BF}$ & CFF \\
\hline $0-7$ & 3.4 & 1.88 & 4.83 & 46.81 & 51.87 & 51.32 & 43.30 & 0.94 & 1.21 \\
\hline $7-15$ & 5.6 & 1.05 & 1.89 & 43.92 & 49.34 & 57.82 & 48.79 & 0.80 & 1.02 \\
\hline $15-27$ & 6.9 & 0.00 & 2.31 & 40.69 & 45.63 & 59.31 & 52.21 & 0.69 & 0.88 \\
\hline $27-33$ & 4.0 & 1.79 & 0.40 & 39.38 & 41.80 & 58.84 & 57.79 & 0.68 & 0.73 \\
\hline $33-72$ & 5.0 & 2.44 & 3.19 & 48.74 & 52.23 & 48.81 & 44.57 & 1.06 & 1.22 \\
\hline $72-122$ & 4.0 & 0.23 & 1.12 & 42.58 & 47.48 & 57.19 & 51.40 & 0.77 & 0.97 \\
\hline $122-127$ & 5.0 & 2.71 & 7.70 & 54.14 & 55.49 & 43.17 & 36.81 & 1.29 & 1.54 \\
\hline $127-142$ & 4.0 & 0.58 & 0.62 & 41.14 & 46.65 & 58.28 & 52.73 & 0.73 & 0.91 \\
\hline $142-150$ & 5.0 & 0.31 & 2.14 & 47.72 & 51.74 & 51.98 & 46.12 & 0.92 & 1.13 \\
\hline
\end{tabular}


Table 5

\begin{tabular}{rcc|ccc}
\hline \multicolumn{2}{l|}{ Oedometer tests } & & \multicolumn{3}{|c}{ Dissipation tests } \\
\hline $\begin{array}{r}\text { Depth } \\
\text { (mbsf) }\end{array}$ & Sample/ID & $\begin{array}{c}\Delta \mathrm{u}_{\text {oedo }} \\
(\mathrm{kPa})\end{array}$ & $\begin{array}{c}\text { Depth } \\
(\mathrm{mbsf})\end{array}$ & Sample/ID & $\begin{array}{c}\Delta \mathrm{u}_{\mathrm{e}} \\
(\mathrm{kPa})\end{array}$ \\
\hline 4.3 & $\mathrm{~S} 3$ & 0.0 & - & - & - \\
11.7 & - & - & 11.7 & $\mathrm{DT} 1$ & 60.0 \\
12.2 & $\mathrm{~S} 8$ & 31.4 & - & - & - \\
16.8 & $\mathrm{~S} 9$ & 45.1 & - & - & - \\
32.6 & $\mathrm{~S} 14$ & 133.1 & 32.6 & $\mathrm{DT} 2$ & 15.0 \\
36.0 & $\mathrm{~S} 15$ & 153.5 & - & - & - \\
45.0 & $\mathrm{~S} 20$ & 212.5 & - & - & - \\
59.9 & - & - & 59.9 & DT3 & 165.0 \\
\hline
\end{tabular}


Table 6

\begin{tabular}{lclc}
\hline $\begin{array}{l}\text { Depth interval } \\
(\mathbf{m})\end{array}$ & $\begin{array}{l}\text { Sedimentation } \\
\text { rate }\left(\mathbf{m} \cdot \mathbf{k y r}^{-\mathbf{1}}\right)\end{array}$ & $\begin{array}{l}\boldsymbol{\alpha} \\
\mathbf{( - )}\end{array}$ & $\begin{array}{l}\text { Corrected } \\
\text { sedimentation } \\
\text { rate }\left(\mathbf{m} \cdot \mathbf{k y r}^{-\mathbf{1}}\right)\end{array}$ \\
\hline $0-15$ & 2.0 & 1.21 & 2.4 \\
$15-30$ & 1.7 & 1.25 & 2.1 \\
$30-33$ & 2.3 & 1.27 & 3.0 \\
$33-41$ & 0.9 & 1.27 & 1.1 \\
$41-47$ & 1.2 & 1.28 & 1.5 \\
$47-54$ & 0.5 & 1.28 & 0.6 \\
$54-64$ & 0.7 & 1.29 & 0.9 \\
$64-72$ & 0.1 & 1.30 & 1.9 \\
$72-110$ & 0.6 & 1.31 & 0.8 \\
$110-120$ & 0.3 & 1.32 & 0.4 \\
$120-127$ & 0.2 & 1.34 & 0.3 \\
$127-140$ & 0.4 & 1.35 & 0.5 \\
\hline
\end{tabular}




\section{Figure captions}

Figure 1. Location of the PRGL1 site. CCC, Cap de Creus Canyon; LDC, Lacaze-Duthiers Canyon; PC, Pruvot Canyon; AC, Aude Canyon; HC, Hérault Canyon; SC, Sète Canyon; MC, Montpellier Canyon; PRC, Petit Rhône Canyon; GRC, Grand Rhône Canyon. Bathymetry in meters from Berné et al. (2001) and Medimap Group (2005). 100 m contour equidistance unless otherwise indicated. Names after Canals (1985).

Figure 2. The piezocone penetrometer. Figure 2a illustrates CPT/CPTU deployment from a drilling vessel in deep water. Figure $2 \mathrm{~b}$ shows where cone tip resistance, $q_{c}$, sleeve friction, $f_{s}$ and excess pore pressure, $u$, are measured. The filter used in the present study for $u$ measurements is located behind the cone tip, $u_{2}$. Figure 2c illustrates the location of the straingauge load cells that measure $f_{s}$ and $q_{c}$ altogether.

Figure 3. CPTU profiles from borehole PRGL1_3 borehole. $q_{c}$ is the cone tip resistance, $f_{s}$ is the sleeve friction and $u_{2}$ the pore pressure. $3 \mathrm{~m}$ spaced $u_{2}$ negative peaks are losses in CPTU readings and, therefore, are unrelated to soil type changes.

Figure 4. Estimation of preconsolidation pressure and results from oedometer tests. Figure 4a illustrates the Casagrande's method for obtaining the preconsolidation pressure $\left(\sigma_{\text {pa }}\right)$. The calculation of $\sigma_{\text {pa }}$ comprises the following steps: (1) construction of the straight-line part (BC) of the curve, (2) determination of the point $\mathrm{D}$ of maximum curvature on the recompression part (AB) of the curve, (3) drawing the tangent to the curve at $\mathrm{D}$ and bisect the angle between the tangent and the horizontal through $\mathrm{D}$, and (4) drawing the line through the point of intersection of the bisector and CB. Figure 4b displays the bi-logarithmic method of Onitsuka for obtaining $\sigma_{p c}^{\prime}$, based on the intersection of the straight-line BC and the straight-line EF. Figure 4c shows the curves obtained from the six oedometer tests on samples S3, S8, S9, S14, S15 and S20 (see Tables 3 and 5).

Figure 5. Preconsolidation pressure $\left(\sigma_{\mathrm{p}}^{\prime}\right)$ at PRGL1 site. Figure 5 a shows continuous $\sigma^{\prime}{ }_{p}$ profiles estimated from the site-specific $\mathrm{N}_{\sigma \mathrm{t}}$ profile (black line) and the $\mathrm{N}_{\sigma \mathrm{tt}}=3.4$ (grey line, after Demers and Leroueil 2002); $\sigma_{\text {vo }}$ corresponds to the vertical effective stress and the red circles to $\sigma_{\mathrm{pb}}^{\prime}$ values interpreted from oedometer tests. Figure $5 \mathrm{~b}$ illustrates overconsolidation $\left(\sigma_{\mathrm{p}}>\sigma^{\prime}{ }_{\mathrm{vo}}\right)$ from 0 to $12 \mathrm{mbsf}$ according to the site-specific $\mathrm{N}_{\sigma \mathrm{\sigma}}$ and from 0 to $30 \mathrm{mbsf}$ based on a 
constant $\mathrm{N}_{\sigma \mathrm{t}}=3.4$ (after Demers and Leroueil 2002). Figure 5c shows a detail of the excess pore pressure $\left(\sigma_{\mathrm{p}}^{\prime}<\sigma^{\prime}{ }_{\mathrm{vo}}\right)$ found from 12 mbsf down to the borehole bottom.

Figure 6. Excess pore pressure $(\Delta \mathrm{u})$ and overpressure ratio $\left(\lambda^{*}\right)$ at PRGL1 site. $\Delta \mathrm{u}_{\text {oedo }}$ measurements are derived from oedometer tests, $\Delta \mathrm{u}_{\mathrm{CPTU}}$ from in situ tests, $\Delta \mathrm{u}_{\mathrm{e}}$ from dissipation tests, and $\Delta \mathrm{u}_{\mathrm{LOGS}}$ from the P-wave downhole logging profile.

Figure 7. Equilibrium pore pressure $\left(\Delta \mathrm{u}_{\mathrm{e}}\right)$ measured during CPTU dissipation tests. Figure 7a corresponds to dissipation test DT1 at 11.7 mbsf, Figure 7b to dissipation test DT2 at 32.6 mbsf and Figure 7c to dissipation test DT3 at 59.9 mbsf.

Figure 8. Correlation amongst overpressure ratio $\left(\lambda^{*}\right)$, sand contents and a seismic reflection profile across site PRGL1 site. Sand contents correspond to both the bulk fraction (BF) and the carbonate free fraction (CFF). Seismic amplitude scale in upper right corner. Pink fringes from 24-27 mbsf, 34-36 mbsf, 46-52 mbsf and 122-127 mbsf correspond to overpressure sources SI to SIV. The dotted lines at 12 and 72 mbsf mark the boundaries between the main units described in the text. The dashed lines show the correspondence between overpressure source SIV and the shallowest high amplitude anomaly associated to the labelled pockmark.

Figure 9. Shansep $\left(\mathrm{Su} / \sigma^{\prime}{ }_{\mathrm{v} 0}\right)$ factor from CPTU based undrained shear strength. Black and grey lines correspond to lower and upper bounds of the Shansep factor, calculated from respective lower and upper Su values $\left(\mathrm{Su}_{\min }\right.$ and $\left.\mathrm{Su}_{\max }\right)$. Stars correspond to $\mathrm{Su}$ values measured by in situ shear vane measurements. Line at $\mathrm{Su} / \sigma^{\prime}{ }_{\mathrm{v} 0}$ equal to 0.25 corresponds to the boundary between underconsolidated and normally consolidated conditions.

Figure 10. CPTU behaviour in the sand-bearing overpressurized layers identified. Relative high sand contents (mainly in the CFF, Fig. 8) are characterized by increases in cone resistance $\left(q_{c}\right)$ and a reduced pore pressure $\left(u_{2}\right)$ due to the permeability of sand.

Figure 11. Sand contents and overpressure sources at site PRGL1 compared to sea level oscillations from Sidall et al. (2003). Sand contents correspond to both the bulk fraction (BF) and the carbonate free fraction (CFF). The borehole depth scale has been converted into an age scale after the inferred age model in Table 2. Note that the top age is 14 kyr. Pink fringes at 2426, 33-38, 46-55 and 220-238 kyr correspond to overpressure sources SI to SIV. The dotted 
lines at 20, 123, 130 and 193 kyr mark the boundaries between overall sea level fall (SLF) and rise periods.

Figure 12. Time needed for the dissipation process of the pore pressure during the last sea level rise. Figure 12a shows $\lambda^{*}$ profiles obtained from Equation 13 (Appendix D.1) and showing excess pore pressure dissipation during the last sea level rise (from $20 \mathrm{kyr}$ to present). Figure 12b shows the profile of the hydraulic diffusivity used in the calculation based on Equation 14 (Appendix D.2). 


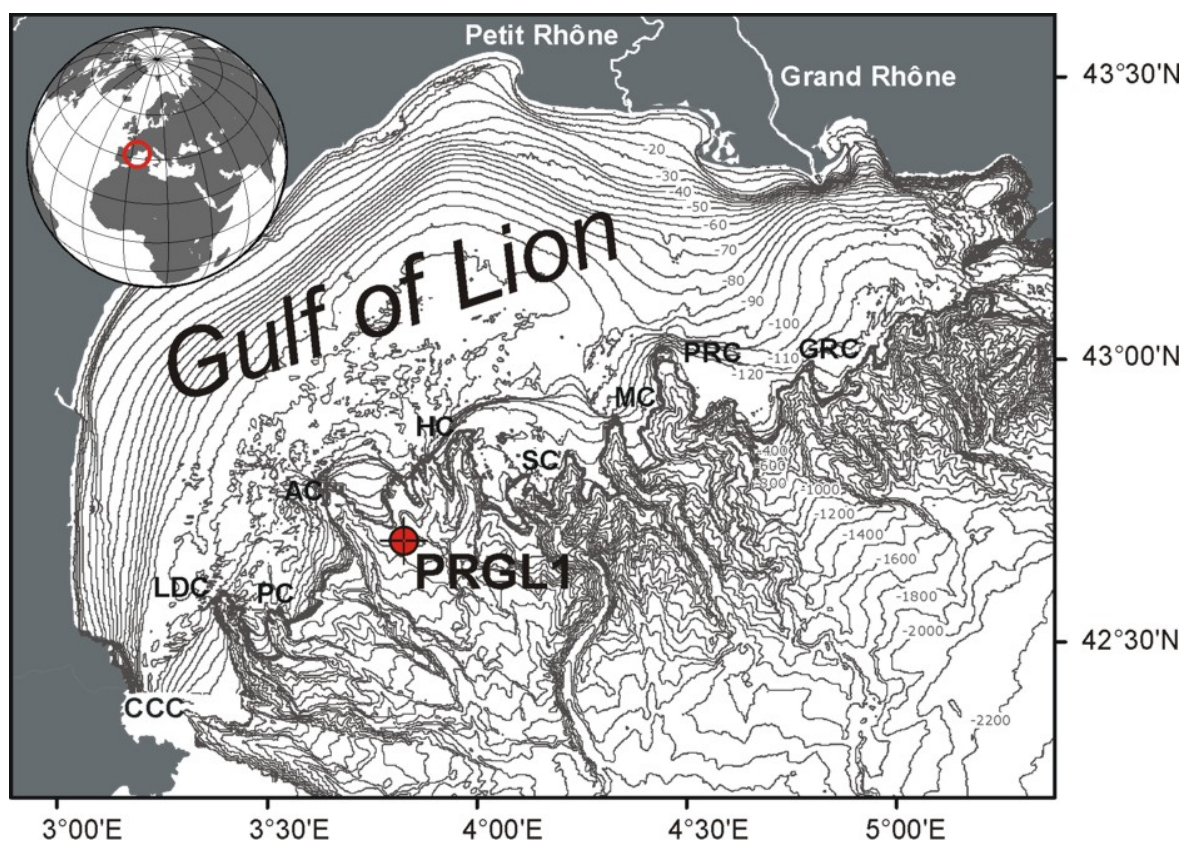

Figure 1
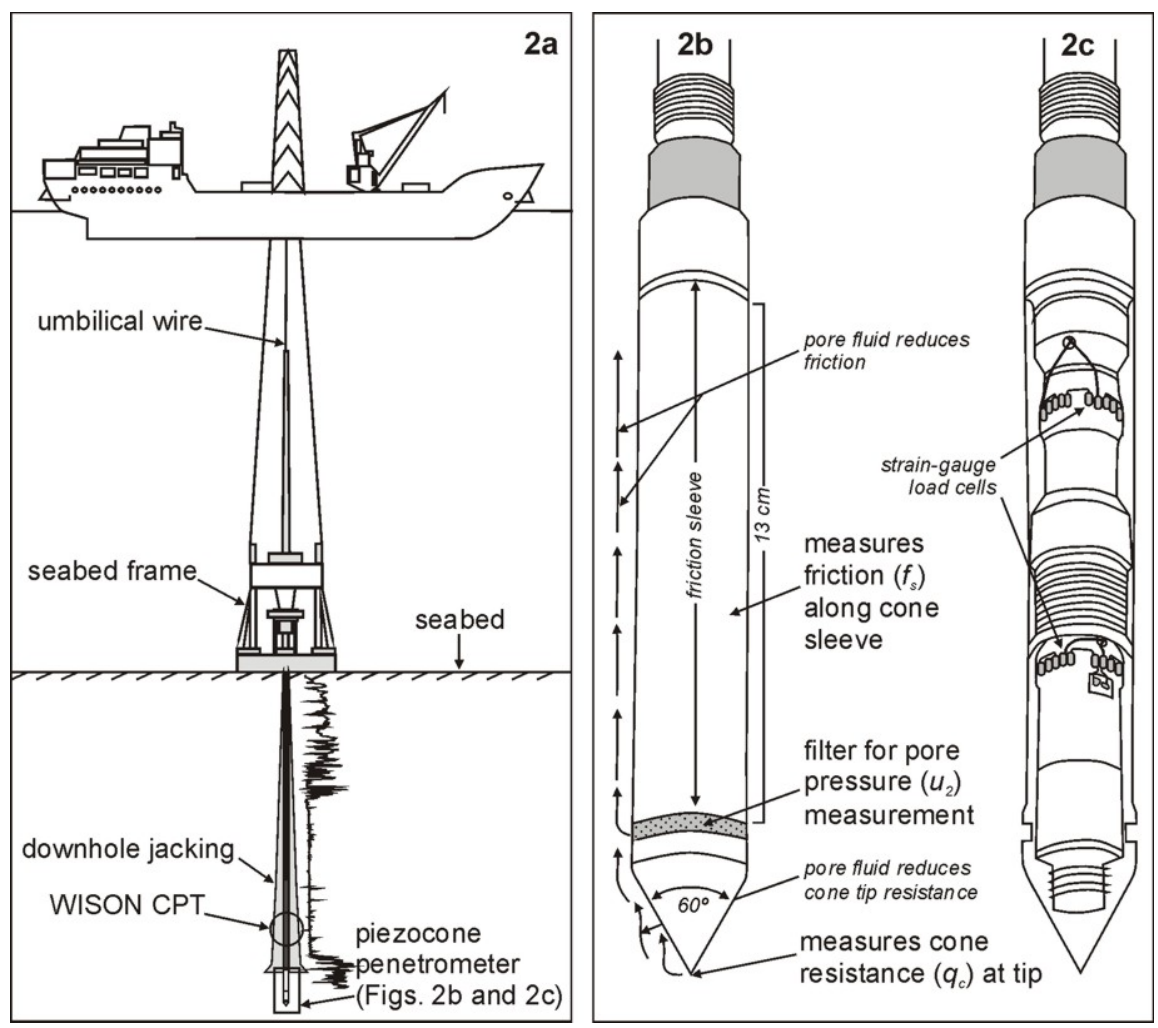

Figure 2 


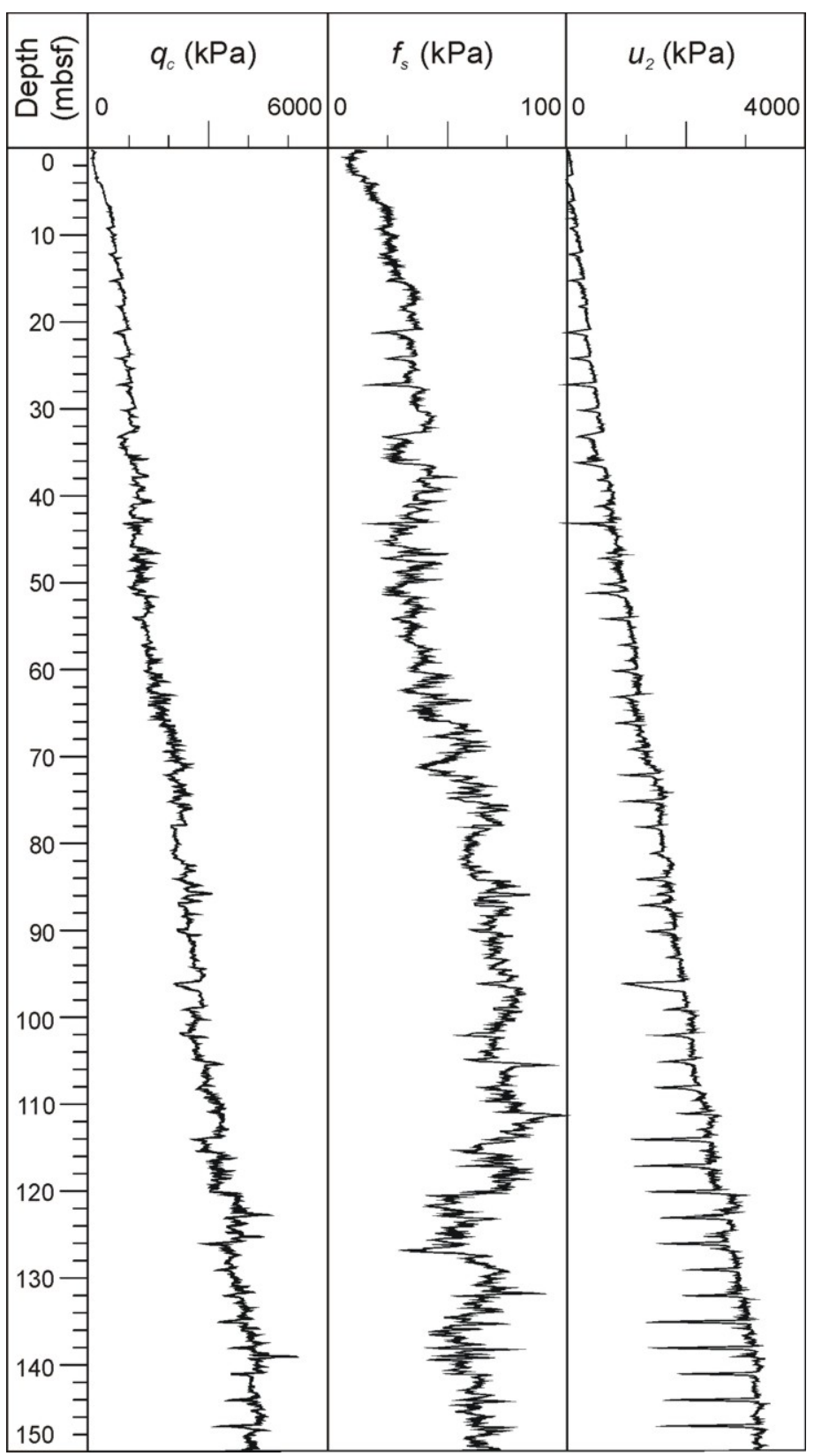

Figure 3 


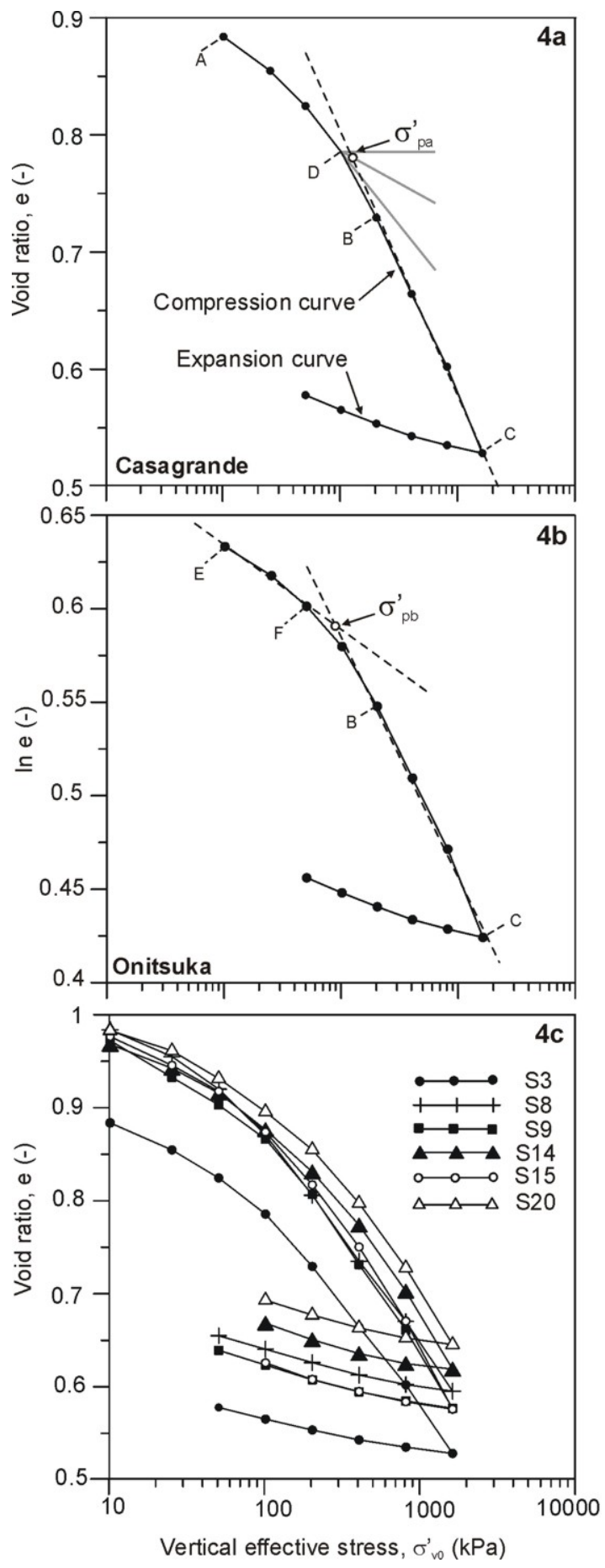

Figure 4 


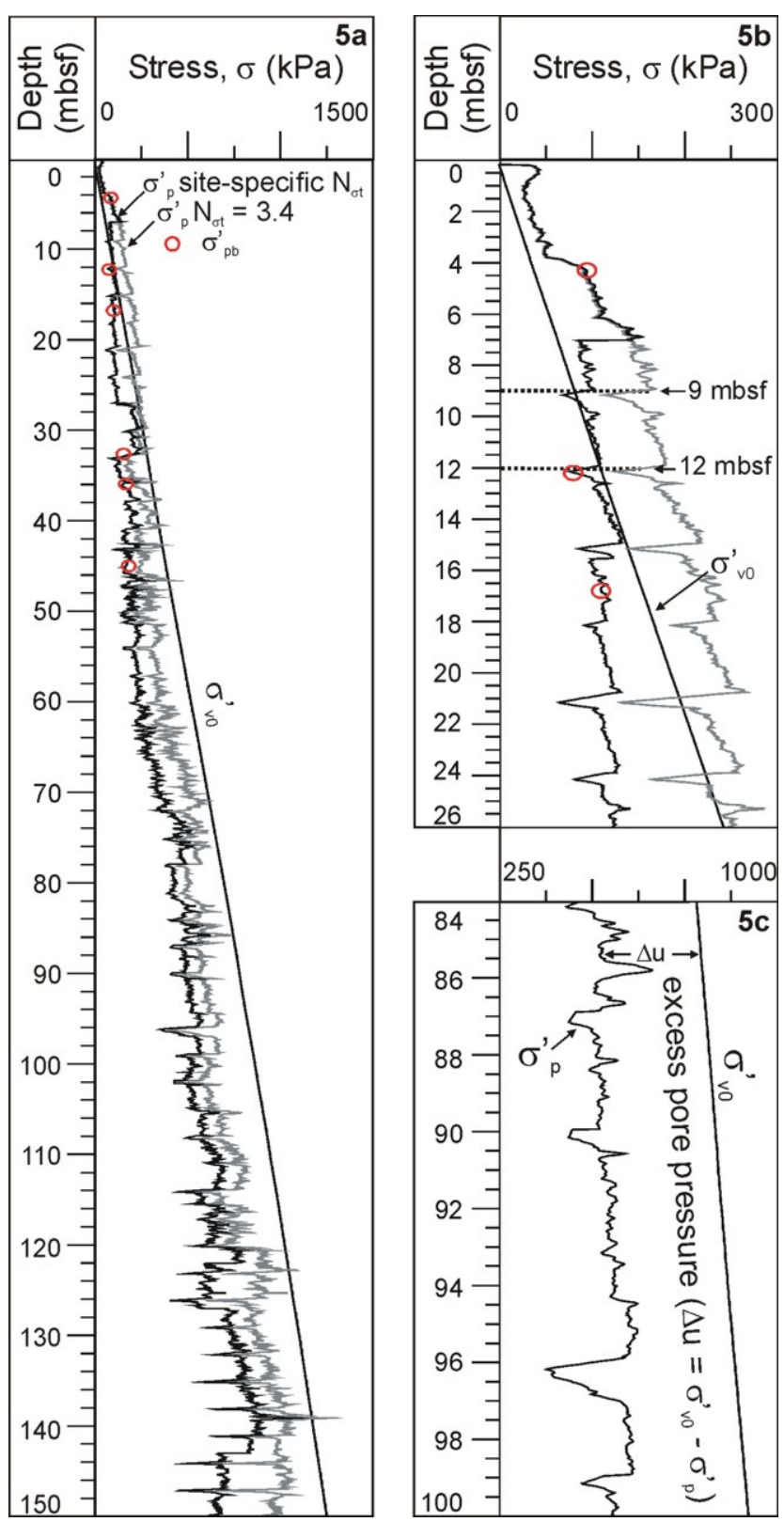

Figure 5 


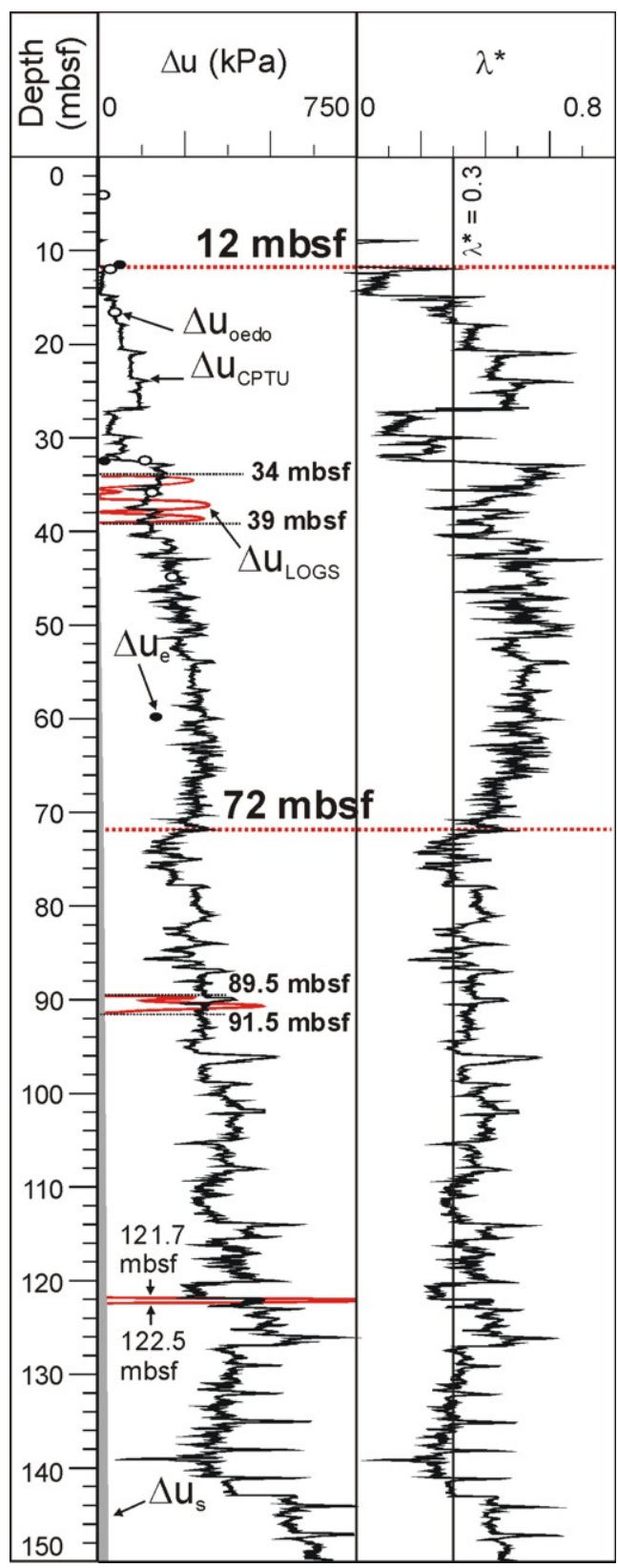

Figure 6 

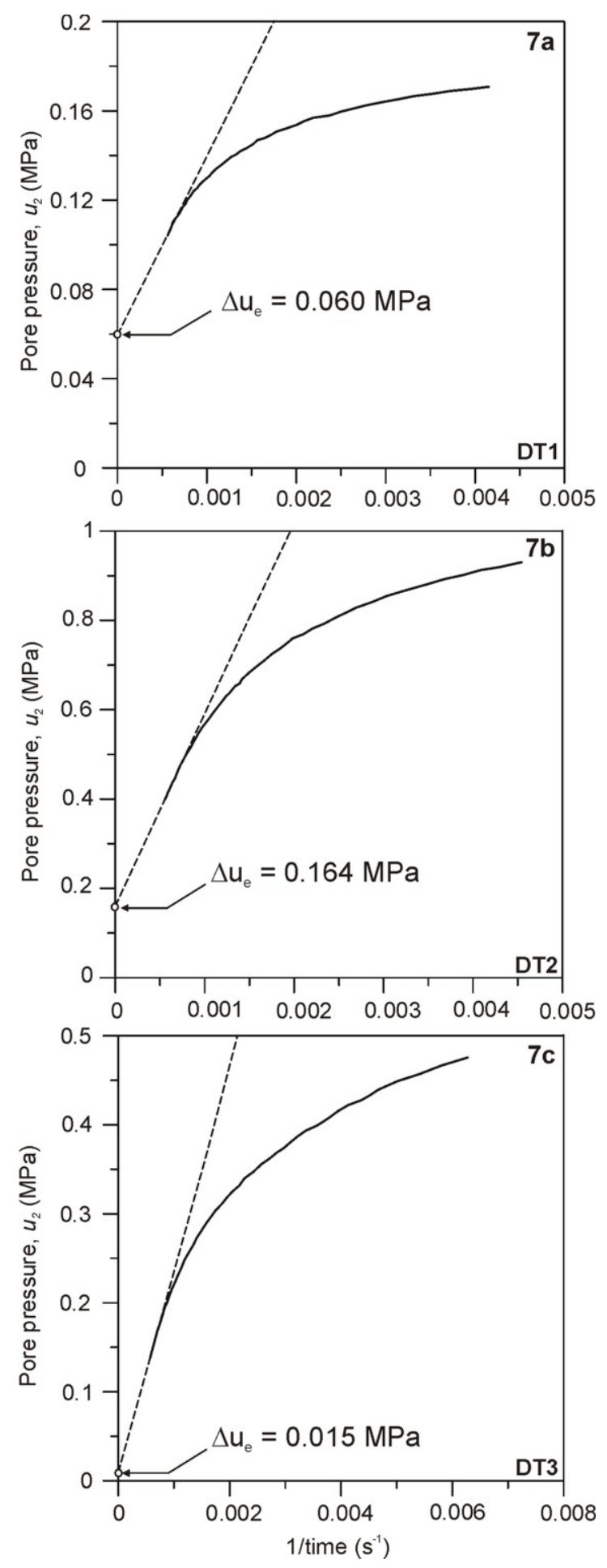

Figure 7 


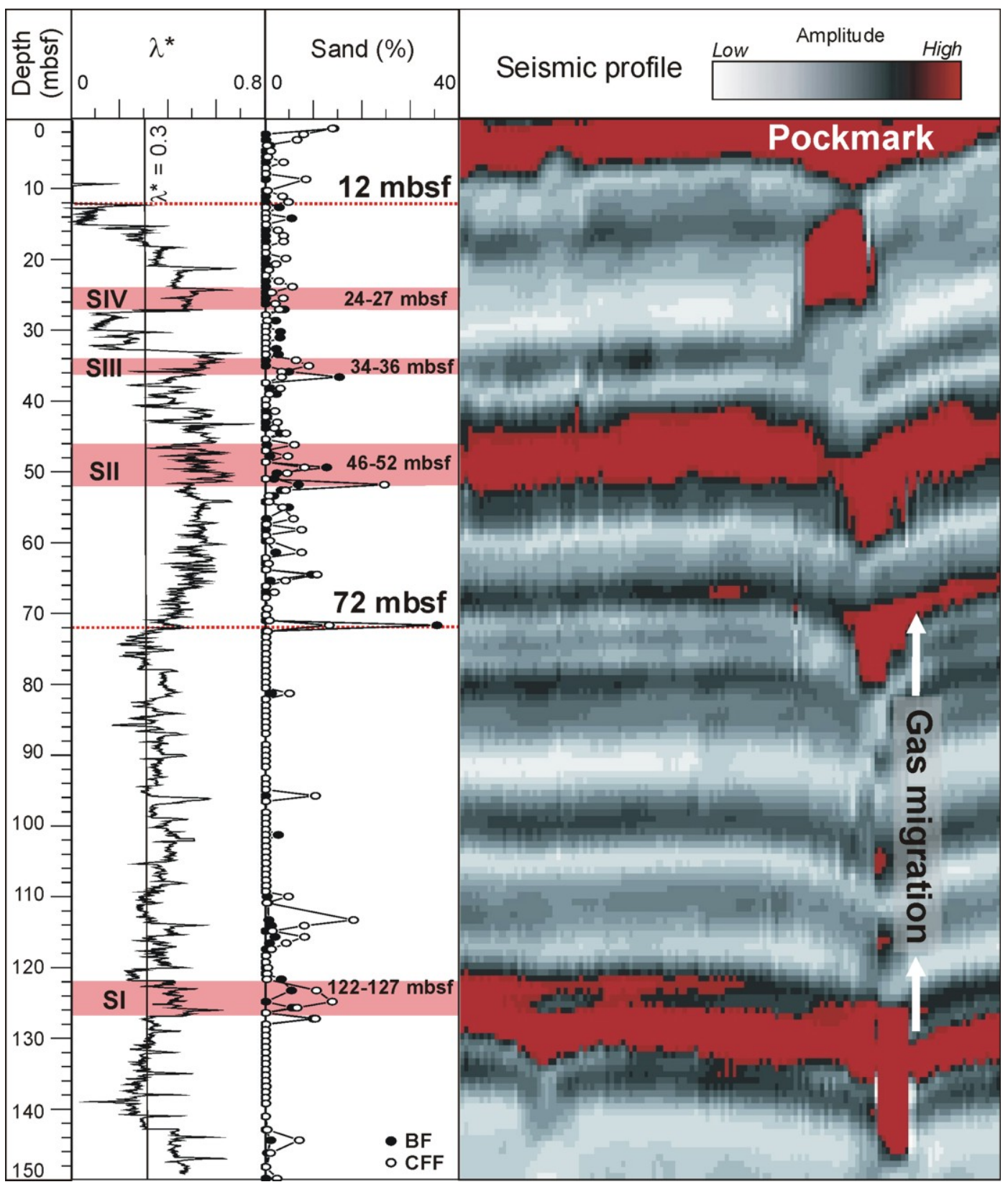

Figure 8 


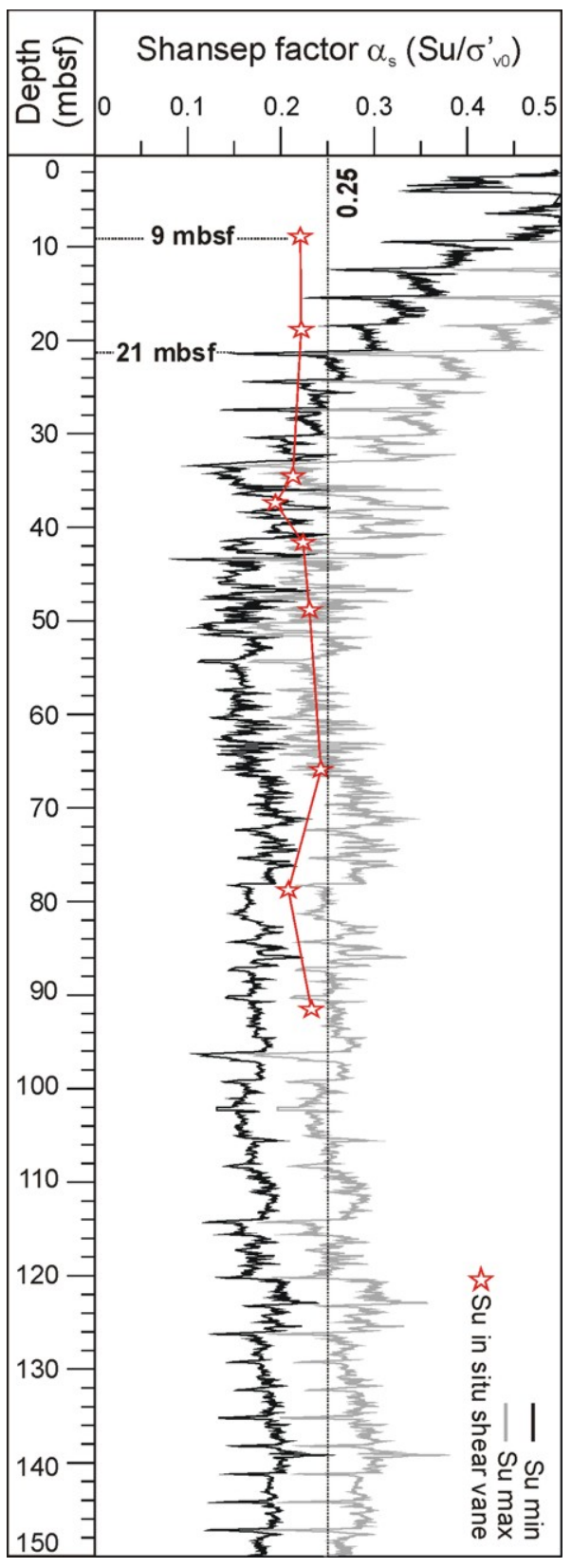

Figure 9 


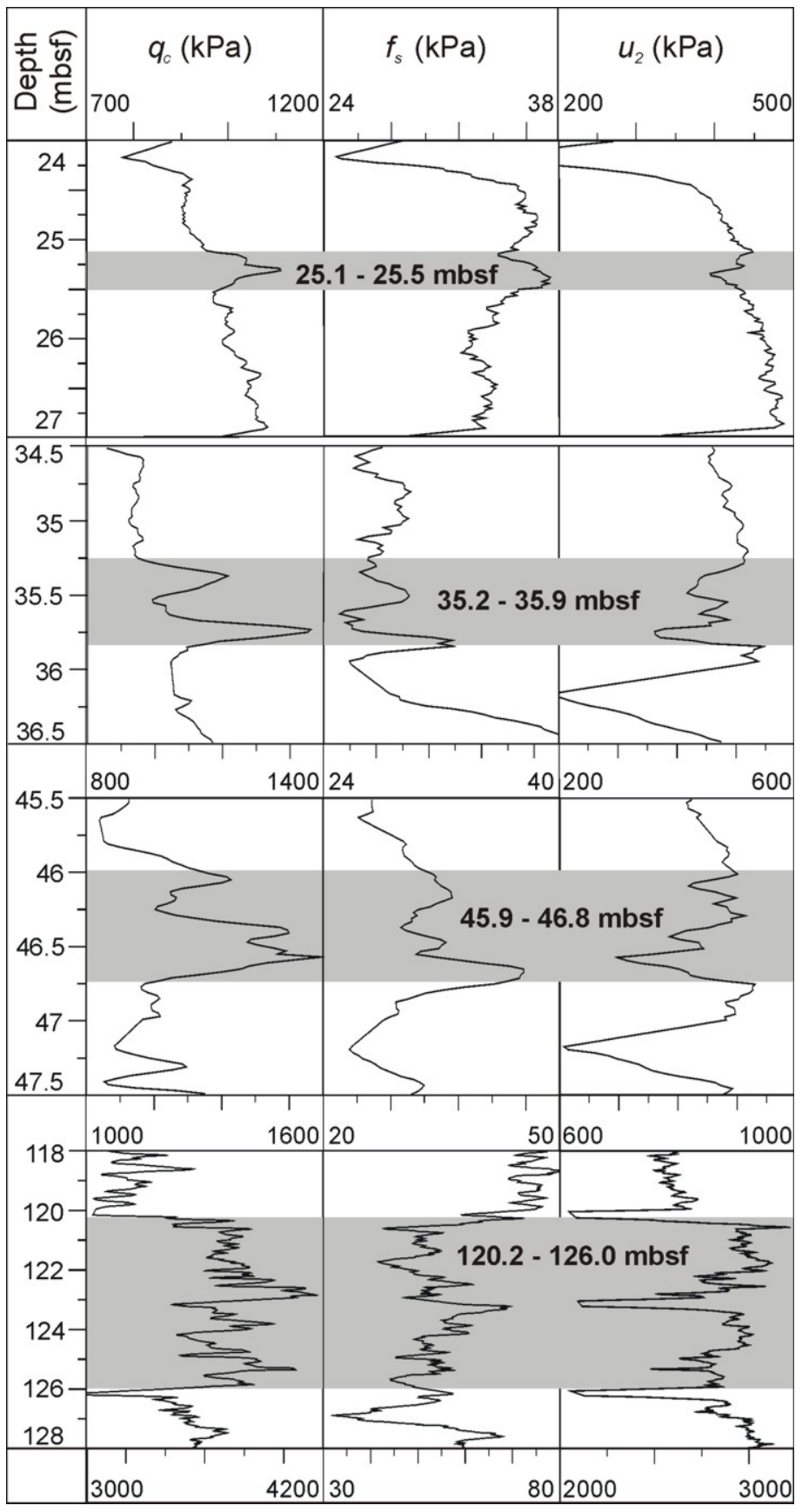

Figure 10 


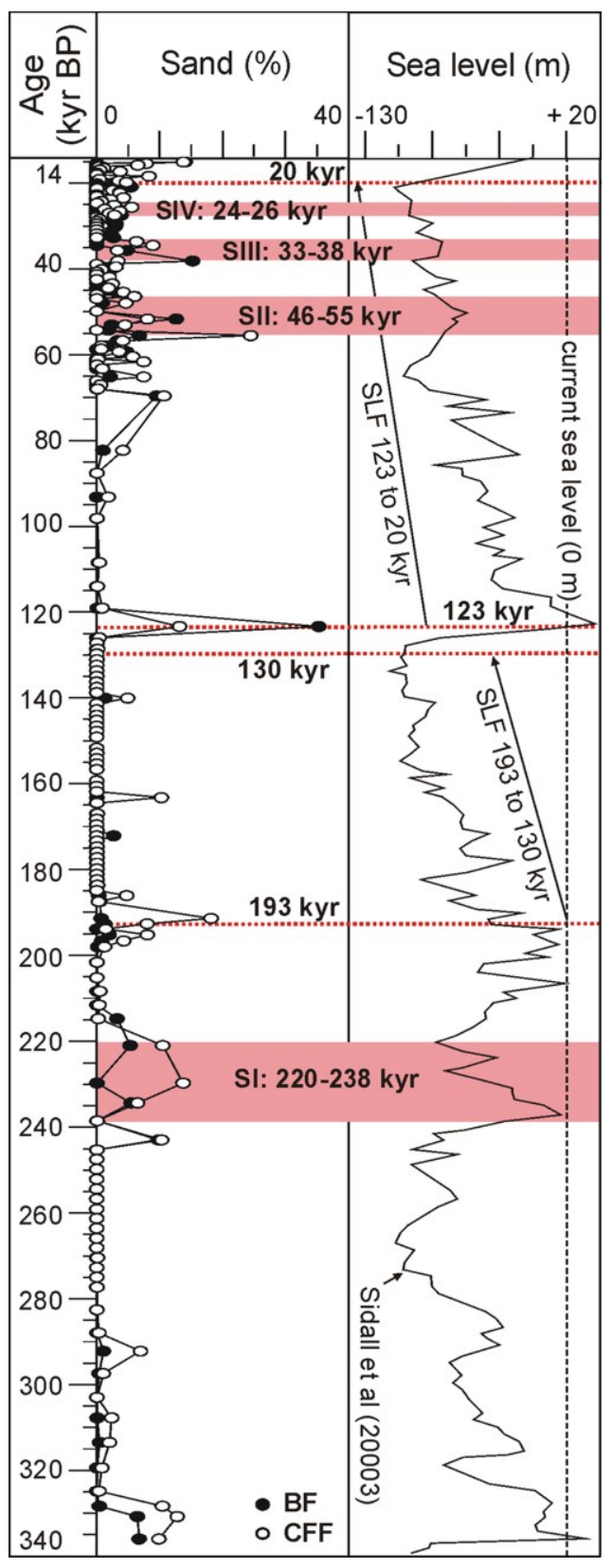

Figure 11 


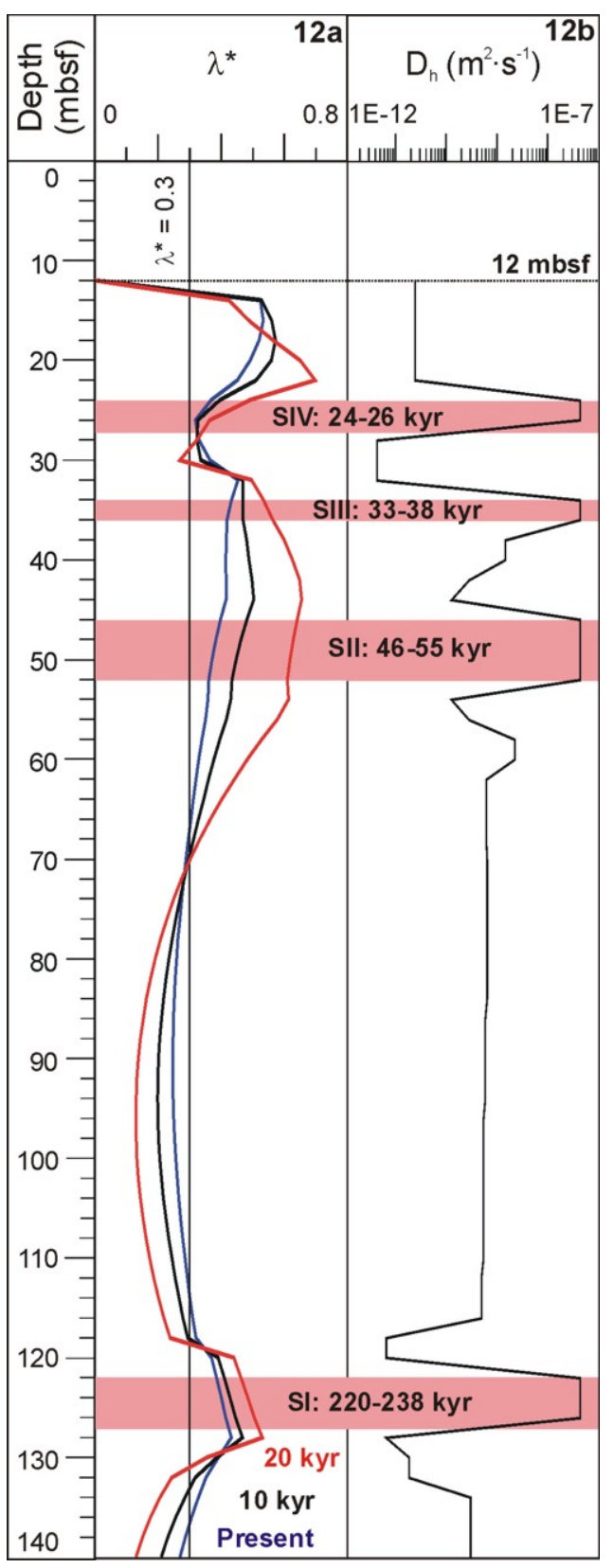

Figure 12 


\section{Appendix A}

\section{A.1. CPTU background information}

Corrections and derived parameters: Due to the geometric design of the piezocone penetrometer, the pore pressure acts on the shoulder above the tip and at both ends of the friction sleeve. This influences the total stress measured from the cone tip resistance, $q_{c}$, and the sleeve friction, $f_{s}$. This is known as the "unequal area effect" (Lunne et al. 1997). CPTU data are interpreted by using derived parameters, such as corrected tip resistance, $q_{t}$ (Equation 1), which accounts for avoiding the unequal area effect. In fine-grained sediments, $q_{c}, f_{s}$ and $u$ tend to increase with increasing overburden stress, resulting in a false change in the CPTU soil type classification. To solve this problem, the direct CPTU parameters are usually normalized, being the net tip resistance, $q_{\text {net }}$ (Equation 2) and the normalized tip resistance, $\mathrm{Q}_{\mathrm{t}}$ (Equation 3) useful parameters for stratigraphic interpretations:

$q_{t}=q_{c}+u_{2} \cdot(1-a)$

$q_{\text {net }}=q_{t}-\sigma_{\mathrm{v} 0}$

$\mathrm{Q}_{\mathrm{t}}=\left(q_{t}-\sigma_{\mathrm{v} 0}\right) / \sigma_{\mathrm{v} 0}$

where a is the cone area ratio of the cross-sectional area at the gap between cone and friction sleeve to the cone base area, which is 0.75 in this study. $\sigma_{\mathrm{vo}}$ is the total in situ vertical stress relative to seafloor and $\sigma^{\prime}{ }_{\text {vo }}$, the vertical effective stress.

Dissipation tests: The piezocone can be stopped at any depth during penetration and this allows monitoring the variation with time of the measured parameters. Dissipation curves are used for estimating the equilibrium pore pressure, which is the in situ pore pressure, by relating the measured pore pressure with 1/time of dissipation.

\section{A.2. Grain size analyses}

The grain size data presented in this study were obtained with a Coulter LS100 Laser Particle Size Analyser. Sampling frequency was each $80 \mathrm{~cm}$. Grain size analyses were done on the bulk fraction (BF) and on the carbonate free fraction (CFF). Carbonate was removed by attack with HCl 10\%. Sand ( $>63 \mu \mathrm{m})$, silt $(2-63 \mu \mathrm{m})$ and clay $(<2 \mu \mathrm{m})$ fractions were determined. The clay fraction underestimation attributed to difractometers like the Coulter Counter if compared with results from pipette analysis (McCave et al. 1995) was corrected following Konert and Vandenberghe (1997). Therefore, the Coulter Counter fraction $<8 \mu \mathrm{m}$ was considered 
equivalent to the $<2 \mu \mathrm{m}$ pipette analysis fraction, while the 8-63 $\mu \mathrm{m}$ Coulter Counter fraction was considered equivalent to the 2-63 $\mu$ m pipette fraction.

\section{Appendix B}

\section{Methodology for CPTU and laboratory based stress history analysis}

Definition of preconsolidation pressure and overconsolidation ratio: If the present vertical effective stress $\left(\sigma^{\prime}\right.$ vo $)$ is the highest the soil has ever been submitted, i.e. the preconsolidation pressure $\left(\sigma_{p}\right)$, the soil is normally consolidated. If some time in the past the effective stress has been larger than the present one, the soil is overconsolidated. If the present vertical effective stress is less than it should be according to the burial depth of the investigated sediment layer, then it is underconsolidated. The highest past vertical effective stress divided by its present value is known as the overconsolidation ratio (OCR), as Equation [4] shows:

OCR $=\sigma_{p}^{\prime} / \sigma_{v 0}^{\prime}$

where $\sigma_{\text {vo }}^{\prime}$ is the vertical effective stress considering hydrostatic conditions $\left(\sigma^{\prime}{ }_{v o}=\sigma_{v o}-u_{h}\right)$. If OCR $>1$ the soil is overconsolidated; if OCR $=1$ the soil is normally consolidated; if OCR $<1$ the soil is underconsolidated.

CPTU approach: Based on the evaluation of the existing methods for estimating $\sigma^{\prime}$ from CPTU data published by Demers and Leroueil (2002), a continuous, site-specific $\mathrm{N}_{\sigma \mathrm{t}}$ profile has been determined. For this, the $\mathrm{N}_{\sigma \mathrm{t}}$ derived from the $\sigma_{\mathrm{p}}$ estimated from the oedometer tests has been related to changes in grain size distributions. This approach is derived from the following expression:

$\mathrm{N}_{\sigma \mathrm{t}}=\left(\mathrm{q}_{\mathrm{t}}-\sigma_{\mathrm{v} 0}\right) / \sigma_{\mathrm{p}}$

\section{Appendix C}

\section{C.1. Overpressure and related concepts}

Overpressure and excess pore pressure: Overpressure exists when there is an excess pore pressure, $\Delta \mathrm{u}$, which is interpreted as the difference between the current effective stress $\left(\sigma^{\prime}{ }_{\text {vo }}\right)$ and the preconsolidation pressure $\left(\sigma^{\prime}{ }_{p}\right)$, as follows: 
$\Delta \mathrm{u}=\sigma_{\mathrm{vo}}-\sigma_{\mathrm{p}}$

Overpressure estimated from downhole logs: A simple empirical function relating P-wave velocity and porosity $(\phi)$ called “time average equation” (Wyllie et al. 1956) has been applied to calculate a continuous $\phi$ profile according to Equation [7]:

$\mathrm{Vp}=\phi \cdot \mathrm{Vp}_{\mathrm{w}}+(1+\phi) \cdot \mathrm{Vp}_{\mathrm{s}}$

where $\mathrm{Vp}$ is the compressional wave (P-wave) velocity, $\mathrm{Vp}_{\mathrm{w}}$ the $\mathrm{Vp}$ of the fluid, e.g. $1500 \mathrm{~m} \mathrm{~s}^{-1}$ and $\mathrm{Vp}_{\mathrm{s}}$ the $\mathrm{Vp}$ of the sediment (solid grain), e.g. mean of $1700 \mathrm{~m} \mathrm{~s}^{-1}$ in clays (Nafe and Drake 1957). On the other hand, porosity and the void ratio are related by:

$\mathrm{e}=\phi /(1-\phi)$

From Equation [8], a continuous void ratio profile is derived, which can be directly utilised for calculating a secondary $\sigma_{p}$ profile, by means of the following compressibility equation:

$\mathrm{e}-\mathrm{e}_{\mathrm{o}}=-\lambda \cdot \ln \left(\sigma_{\mathrm{p}}{ }_{\mathrm{p}} / \sigma^{\prime}{ }_{\mathrm{vo}}\right)$

where $e_{o}$ is the reference void ratio at a vertical effective stress of $\sigma^{\prime}{ }_{v 0}, \lambda$ is the compression index and $\sigma_{p}^{\prime}$ the preconsolidation pressure. $e_{o}$ and $\lambda$ are determined from oedometer tests. $\sigma_{p}$ p calculated from Equation [9] is used to estimate the overpressure, $\Delta \mathrm{u}_{\mathrm{LOGS}}$, by means of Equation [6].

Overpressure ratio: The excess pore pressure, $\Delta \mathrm{u}$, is the pressure gradient that is usually converted to an adimensional ratio of the magnitude of overpressure, which is defined as follows:

$\lambda^{*}=\left(\Delta \mathrm{u}-\mathrm{u}_{\mathrm{h}}\right) /\left(\sigma_{\mathrm{vo}}-\mathrm{u}_{\mathrm{h}}\right)$

where $\mathrm{u}_{\mathrm{h}}$ is the hydrostatic pressure and $\sigma_{\mathrm{vo}}$ the total vertical stress (Expedition 305 Scientists 2005).

Excess pore pressure generated by sedimentation: Following Sultan et al. (2004), the excess pore pressure generated by sediment accumulation, $\Delta \mathrm{u}_{\mathrm{s}}$, is calculated from (i) biostratigraphy derived average sedimentation rates from PRGL1_4 borehole, (ii) the reference void ratio $\left(\mathrm{e}_{\mathrm{o}}\right)$, and (iii) the compression index $(\lambda)$ derived from oedometer tests. The average sedimentation rates are corrected by multiplying them by the so-called factor $\alpha$ (Equation 11) (Dennielou et al. 
2006) that accounts for the difference between the initial sediment height before consolidation and the final sediment height:

$\alpha=1-\left[\left(\lambda / 1+\mathrm{e}_{\mathrm{o}}\right) \cdot \ln \left(\sigma^{\prime}{ }_{\mathrm{v}} / \sigma^{\prime}{ }_{\mathrm{vo}}\right)\right]$

where $\lambda$ is the compression index, $\mathrm{e}_{\mathrm{o}}$ a reference void ratio at a reference vertical effective stress $\sigma^{\prime}{ }_{\text {vo }}$, and $\sigma^{\prime}{ }_{\mathrm{v}}$ the effective stress (definitions already provided). Here $\sigma^{\prime}{ }_{\mathrm{v}}$ corresponds to the notation $\sigma_{\text {vo }}^{\prime}$ used in Equation [3] in Appendix A, [4] in Appendix B and [6] in Appendix C.

\section{C.2. Shear strength from CPTU data}

An estimate of the undrained shear strength Su can be deduced from the following equation:

$\mathrm{Su}=\mathrm{q}_{\mathrm{net}} / \mathrm{N}_{\mathrm{k}}$

We have calculated the lower and upper boundaries of Su by using the empirical cone factor $\mathrm{N}_{\mathrm{k}}$ equal to 15 and 10, respectively (Lunne et al. 1997).

\section{Appendix D}

\section{D.1. Gas release and exsolution as a continuous flow}

The time dissipation $t$ of this pore pressure depends mainly on 2 key parameters: the longest drainage distance $h$ and the hydraulic diffusivity $\mathrm{D}_{\mathrm{h}}$ :

$t=\left(\mathrm{T}_{\mathrm{v}} \cdot \mathrm{h}^{2}\right) / \mathrm{D}_{\mathrm{h}}$

where $T_{v}$ is a non-dimensional time factor. $T_{v}$ was given as a function of the degree of dissipation by Casagrande (1936) and Taylor (1948). For a degree of dissipation of $93 \%, \mathrm{~T}_{\mathrm{v}}$ is equal to 1 .

\section{D.2. Dissipation of the pore pressure}

The key differential equation used for this process was given by Terzaghi (1943):

$D_{h} \frac{\partial^{2} u}{\partial z^{2}}=\frac{\partial u}{\partial t}$

where $u$ is the pore water pressure, $t$ is time and $z$ denotes the position where $u$ is determined. 


\section{Notations}

Symbol Definition and units

$\Delta \mathrm{u}$

excess pore pressure or overpressure, $\mathrm{kPa}$

$\mathrm{D}_{\mathrm{h}}$

hydraulic diffusivity, $\mathrm{m}^{2} \cdot \mathrm{s}^{-1}$

$\sigma_{\text {vo }}^{\prime}$

vertical effective stress, $\mathrm{kPa}$

$\sigma_{\mathrm{vo}}$

total vertical stress, $\mathrm{kPa}$

$\sigma_{\mathrm{p}}^{\prime}$

preconsolidation pressure, $\mathrm{kPa}$

$\mathrm{u}_{\mathrm{h}}$

pore fluid pressure considering hydrostatic conditions, $\mathrm{kPa}$

$\rho_{\mathrm{w}}$

unit weight of the water, $\mathrm{g} \cdot \mathrm{cm}^{-3}$

g gravity, $\mathrm{m} \cdot \mathrm{s}^{-2}$

z depth, $\mathrm{m}$

$q_{c} \quad$ cone tip resistance, $\mathrm{kPa}$

$f_{s}$

sleeve friction, $\mathrm{kPa}$

$u$

pore pressure, $\mathrm{kPa}$

$q_{t}$

corrected cone resistance, $\mathrm{kPa}$

$q_{\text {net }}$

net tip resistance, $\mathrm{kPa}$

$\mathrm{N}_{\sigma \mathrm{t}}$

parameter $\mathrm{N}_{\sigma \mathrm{t}}=\left(\mathrm{q}_{\mathrm{t}}-\sigma_{\mathrm{v} 0}\right) / \sigma_{\mathrm{p}}$ used to calculate preconsolidation pressure $\left(\sigma_{\mathrm{p}}{ }^{\prime}\right)$

$\mathrm{N}_{\mathrm{k}}$

empirical cone factor

$u_{1}$

pore pressure at the cone, $\mathrm{kPa}$

$u_{2}$

pore pressure behind the cone, $\mathrm{kPa}$

$u_{3}$

pore pressure behind the sleeve friction sensor, $\mathrm{kPa}$

$\mathrm{Vp}$

p-wave, $\mathrm{m} \cdot \mathrm{s}^{-1}$

$\mathrm{Vp}_{\mathrm{w}}$

$\mathrm{p}$-wave of the fluid filling voids, $\mathrm{m} \cdot \mathrm{s}^{-1}$

$\mathrm{Vp}_{\mathrm{s}}$

$\mathrm{p}$-wave of the sediment, $\mathrm{m} \cdot \mathrm{s}^{-1}$

$\sigma_{\text {ра }}^{\prime}$

preconsolidation pressures $\sigma_{\mathrm{p}}$, obtained following Casagrande's method, $\mathrm{kPa}$

$\sigma_{\mathrm{pb}}^{\prime}$

preconsolidation pressures $\sigma_{\mathrm{p}}$ obtained following Onitsuka's method, kPa

$\mathrm{u}_{\mathrm{h}}$

hydrostatic pressure, $\mathrm{kPa}$

$\Delta \mathrm{u}_{\mathrm{CPTU}}$

overpressure determined by CPTU, $\mathrm{kPa}$

$\Delta \mathrm{u}_{\mathrm{LOGS}}$

overpressure determined by downhole-logs, $\mathrm{kPa}$

$\Delta \mathrm{u}_{\mathrm{e}}$

equilibrium pore pressure values, $\Delta \mathrm{u}_{\mathrm{e}}, \mathrm{kPa}$

$\Delta \mathrm{u}_{\mathrm{s}}$

excess pore pressure generated by sediment loading, $\mathrm{kPa}$

$\mathrm{e}_{\mathrm{o}}$

reference void ratio 
$\lambda$

compression index

$\lambda^{*}$

adimensional ratio of the overpressure magnitude

$\mathrm{BF}$

bulk sediment fraction, \%

$\mathrm{CFF}$

carbonate free sediment fraction, \%

$\phi$

porosity, \%

OCR

overconsolidation ratio

$\mathrm{T}_{\mathrm{v}}$

non-dimensional time factor 